\title{
TOKAT VOYVODALIĞI
}

(1774-1842)

\author{
MEHMET BEŞIRLI*
}

\section{Giris}

Osmanlı Devleti'nin ilk yüzyılında genelde bütün Anadolu toprakları, özelde ise Amasya, Tokat ve Sivas bölgeleri için Rum tabiri kullanılmıştur. 1413 yılında Anadolu ve Rumeli Beylerbeyliği'nin yanı sıra üçüncü bir idarî birim olarak Rum Beylerbeyliği kurulmuştur ${ }^{1}$. İlk zamanlarda Tokat, Sivas ve Amasya bölgelerinin birleşmesinden meydana gelen Rum Eyaleti'ne II. Murad'ın son zamanlarında Canik ve Çorum, daha sonra da Karahisar-ı Şarkî bölgesi katılmıştur. Aynı dönemde Rum Eyaleti'nin merkez toprakları olan Amasya, Tokat ve Sivas, önemlerine binaen "Eyâlet-i Rûmiyye-i Suğra" olarak adlandırılmışlardır². Ayn Ali Efendi'ye göre, XVII. yüzyılın başında Rum (Sivas) Eyaleti; Sivas, Amasya, Çorum, Bozok, Divriği, Canik ve Arapkir livalarından meydana geliyordu ${ }^{3}$.

1413-1520 yılları arasında Rum Eyaleti'nin merkezi, bazen Şehzade Sancağı Amasya bazen de Tokat oldu. 1520 yilında eyalet merkezi Sivas'a taşındı ve bu tarihten itibaren Rum beylerbeyleri Sivas'ta oturmaya başladılar. Bu yeni düzenleme ile birlikte Tokat şehri, sadece kaza merkezi olarak kaldı.

*Yrd. Doç. Dr., Gaziosmanpaşa Üniversitesi Fen-Edebiyat Fakültesi Tarih Bölümü, TOKAT, mbesirli@gop.edu.tr; mbesirli69@yahoo.de.

${ }^{1}$ Ahmet Şimşirgil, "Osmanlı Taşra Teşkilatunda Rum Beylerbeyliği". Türklük Araşurmaları Dergisi, Sayı 5, İstanbul 1989, s. 290-291. Osmanlı Taşra Teşkilaunda Rum Beylerbeyliği ve Tokat'ın idarî taksimat üzerine geniş bilgi için bk. aym yazar, Osmanlı Taşra Teşkilâtunda Tokat (1455-1574), Marmara Ǘniversitesi Sosyal Bilimler Enstitüsü Basılmamış Doktora Tezi, İstanbul 1990 , s. $28-43$.

2 Tayyib Gökbilgin, "Tokat", İslâm Ansiklopedisi, 2. Bask, İstanbul 1979, s. 406; Erol Ōzvar, "XVII. Yüzyılda Osmanlı Taşra Maliyesinde Değişim: Rum Eyaletinde Hazine Defterdarlığından Tokat Voyvodalığına Geçiş", XIII. Türk Tarih Kongresi, Ankara, 4-8 Ekim 1999, Kongreye Sunulan Bildiriler, III. Cilt, III. Kısım, Ankara 2002, s. 1607.

${ }^{3}$ Ayn Ali Efendi, Kavânin-i Âlî Osman Der-Hülâsa-i Mezâmin-i Defter-i Divân, Osmanlı Kanunnameleri ve Hukuki Tahlilleri, 6. Kitap, İstanbul 1993, s. 56'dan naklen Erol Özvar, XVII. Yüzyılda Osmanlı Taşra Maliyesinde Değişim: Rum Hazine Defterdarlığından Tokat Voyvodalı̆̆ına Geçiş, Marmara Üniversitesi Sosyal Bilimler Enstitūsū Basılmamış Doktora Tezi, Istanbul 1998, s. 15, 17. 
Tokat kazası, 1520'den 1600'lere kadar Merkez Nahiye (Tokat), Cincife, Gelmuğat, Kafirni, Kazabad, Komanat, Tozanlu, Venk ve Yildız olmak üzere toplam dokuz nahiyeden oluşmaktayd ${ }^{4}$.

Osmanlı Devleti, XVII. yüzyılın yeni şartları içinde malî örgütlenmesinde yeni düzenlemelere gitti. Avarız vergilerini daimî hale getiren yönetim, diğer vergi gelirlerini de arturmanın çarelerini aramaya başladı. Bu amaçla vergileri daha iyi toplanmak ve hazineye nakit girişini sağlamak amacıyla mukataa sistemi gittikçe yaygınlaşturıldı. Buna paralel olarak vergi gelirlerini toplamada esas alınan kazaların sayısı da artturıldı. Bu gelişme kısa sürede Tokat'a da yansıdı. Kazaya bağlı bazı nahiyeler kaza statüsüne çıkarıldığından, 1620'lerde Tokat kazasının nahiye sayısı Merkez Nahiye, Cincife, Komanat, Kafirni ve Yıldız olmak üzere dörde düștü ${ }^{5}$. Așağı yukarı aynı dönemlerde kaza dahilindeki padişah hasları Valide Sultan hassı olarak verilmiş ve idaresi de voyvodaya bırakılmıştur.

Tokat Voyvodalığı ihdas edilmeden önce, eyaletteki malî işlemleri "Rum Hazinesi Defterdarlığı" yürütüyordu. Ağustos 1659 tarihinde defterdarlık kaldırılarak, "Tokat Voyvodalığı" ihdas edilmiştir. Yani Rum Eyaleti'nde Hazine Defterdarlı̆̆ı'nın kaldırılarak bu eyaletteki "Havâss-ı Hümâyun”a ait gelir kaynakları, bir bütün olarak "ber-vech-i voyvodalık" iltizama verilmeye başlanmıştur. Devletin bu yola girmesinin altunda yatan en önemli sebep, hazineye peşin olarak akçe girişini sağlamaktı. Çünkü iltizam yoluyla vergi gelirlerinin satşı ıüzayedede ylllık en yüksek peşin ödemeyi taahhüt eden bir mültezime veriliyor, o da vergileri kiralamış oluyordu. Mültezim, hazineye bir kefil gösterir ve bedelin bir kısmını da peşin öderdi. Yani Rum Hazine Defterdarlı̆gı'nın hazine gelirlerinin tamamının iltizam yoluyla voyvodalara satulmasılyla devlet hazinesi, vergi gelirlerini tahsil etmeden önce nakdî gelir elde etmiş olurdu ${ }^{6}$.

1659 tarihinde Tokat Voyvodalığı'na bağlı ve ilk voyvoda olarak Küçük Ahmed'e iltizama verilen mukataalar şunlardı: Hasha-i Osmancık, Maden-i Gümüş, Zile ve Turhal, Hasha-i Artukabad, Gedeğere, Karayaka, Tozanlı,

\footnotetext{
${ }^{4}$ Rum Eyaleti'nin ve Tokat kazasının 1600 yıllarına kadarki sınırlan ve idarî birimleri için bk. A. Șimşirgil, aynı tez, s. 28-43.

${ }^{5}$ Ali Açıkel, Changes in Settlement Patterns, Population and Society in North Central Anatolia: A Case Study of the District (kaza) of Tokat (1574-1643), Basılmamış Doktora Tezi, Manchester Üniversitesi 1999, s. 51-54.

${ }^{6}$ E. Özvar, ayn tez, s. 37, 40-41, 43.
} 
Hargün, Çeltük-i Niksar, Havass-1 Müteferrika, Sonisa, Akdağ ve Budaközü, Olukmanlı, Boyahâne-i Karye-i Kızoğlu, Zeytun, Tamga-i Kasaba-i Zile, Tamga-i Kasaba-i Tozanlı, Karye-i Boyalu, Karye-i Bostanobası, Kalhâne, Dağdaşan, Karye-i Göle ${ }^{7}$.

Ahmed Ağa'nın iltizamı dışında kalan Âsitâne tarafından satılan mukataalar ise şunlardı: Mizân-ı Harîr-i Tokad, Hasha-i Amasya, İspençe-i Gebrân-1 Nefs-i Tokad, Niyâbet-i Kazabad, Hasha-i Çorum, Hasha-i İskilib ve Katar, Ağça Kilise, Kabâil-i Ekrâd-ı Lak, Hasha-i Kırşehri ve Keskin, Karye-i Biskeni, Beytü'l-Mal-1 Hassa, Cizye-i Gebrân-1 Artukabad, Karye-i Komanat-1 Müslim ve Zımmî, Hasha-i Hoca, Boya-i Surh-1 Tokad, Duhhâniyye-i Nefs-i Tokad, Tamga-i Boya-i Surh-1 Amasya, Bedel-i Güherçile-i Eyalet-i Rum ve Memlaha-i Cedid $^{8}$.

Voyvodalar, kendilerine verilen sancaktan küçük gelir bölgelerinin hem idarî yöneticileri hem de hazine gelirlerini toplayan vergi tahsildarları idiler. Kent veya kasabanın güvenliğini sağlamak, gerektiğinde asker toplayıp savaşa kaulmak da görevleri arasındaydı. Sancakta mütesellimin yapuğı idarî görevleri, kendilerine verilen gelirleri yüksek dar bölgede voyvodalar yapmaktaydılar $^{9}$. Yani voyvoda, bazı yerlerde ${ }^{10}$ malî bir birimin başı olarak görülmesine rağmen, Tokat'ta idarî ve gerektiğinde askerî bazı yükümlülükleri yerine getiren ve sancakbeyi yetkilerine haiz görevliyi ifade etmekteydi.

Tanzimat'la yapılan idarî reformlarla birlikte Tokat Voyvodalığı, "Muhassıllık"a dönüştürülerek, malî işleri idare eden bir muhassıl atanmışur. Asayiş, güvenlik ve zaptiye işleri ise, zaptiye memuru vasıtasıyla yönetilmeye başlanmıştır ${ }^{11}$. Ancak başarısız olan muhassıllığın kaldırılmasından sonra, 1842 ylı Mart'ından itibaren Meclis-i Vâlâ kararı ile Tanzimat'ın uy-

${ }^{7}$ Aymi tez, s. 46.

${ }^{8}$ Ayni tez, s. 46 ve ayni yazar, ayn makale, s. 1622.

${ }^{9}$ Musa Cadırcı, Tanzimat Dóneminde Anadolu Kenterinin Sosyal ve Ekonomik Yapılanı. Ankara 1991, s. 30.

${ }^{10}$ Meselâ, Diyarbakur Voyvodalı̆̆ı gibi bazı birimlerde voyvoda sadece malî yükümlülükler yerine getiren bir görevliydi. Bk. İbrahim Yılmazçelik, XIX. Yüzylın IIlk Yarısında Diyarbakır (1790-1840), Ankara 1995, s. 197-204.

11 "Dergâh-ı mu'allâm kapucubaşılarından mülhakâuyla Tokad kazâsı muhassılı Hasan" (Tokat Șer'iyye Sicili, Defter No : 54, Sayfa No : 80, Belge No : 2. Bundan sonra TŞS, 54, 80/2 șeklinde gösterilecektir. Eğer bir sayfada bir adet belge varsa belge numaraları verilmeyecektir) ve "Asâkir-i Mansûre-i şâhânem mîralâylarından Tokad ve tevâbi' kazâları umûr-ı zabtiyesi me'mûrı Mustafa Bey" (TSSS, 54, 46/1) ifadeleri Tanzimat sonrası yeni yōneticileri nitelemektedir. 
gulandığı bütün eyaletlerde kazaların müdürler tarafından yönetilmesi kabul edilmiştir $^{12}$. Bu karar ile Tokat kazası da, müdür tarafından yönetilmeye başlanmışur.

Bu çalışma, Tanzimat öncesinde Sivas Eyaleti'ne bağlı Tokat Voyvodalığı üzerine genel bir araşurmadır. Çalışmanın ana kaynaklarını Tokat şer'iye sicilleri oluşturmaktadır. Sicillerdeki kayıtların verdiği bilgiler çerçevesinde konuyu aydınlatmaya çalıștuk. Teknik olarak tırnak içinde italik olarak verilen kısımlar, belgelerden ya da çalışmalardan alınan alıntuları ihtiva etmektedir. Alıntularda bulunan yer ve şahıs isimleri ile diğer kavramlar yazılırken, orijinal metne sadık kalınmışur. Ancak alınular dışındaki kısımlardaki yazım kurallarında Türk Dil Kurumu'nun İmlâ Kılavuzu (Ankara 2000) esas alınmıştur. Meselâ, "Tokat" kelimesi, alıntularda "Tokad" şeklinde geçmektedir. Çalışmadaki alıntılarda orijinal şekliyle Tokad olarak yazılırken, genel metin içinde ise, bugünkü kullanıldığı Türkçe'ye uyumlu şekliyle yazzlmışur. Kavramlara da bir örnek verirsek, alıntılarda "mâlikâne" şeklinde yazılırken, normal metin içinde İmla Kılavuzu'ndaki şekliyle "malikâne" olarak yazılmıştır. Tırnak içinde verilen italik olmayan kısımlar ise, kavramı vurgulamak içindir. Osmanlı döneminde kullanılan "Darbhâne-i Âmire" gibi özel terimler ise, yine alıntular dışındaki kısımlarda da orijinal haliyle verilmiştir.

Ayrıca bu çalışma, yürütücülüğünü yaptuğımız "Karadeniz Şehirlerinin Sosyal ve Ekonomik Tarihi (1785-1840) I: Tokat - Trabzon - Samsun" adlı Devlet Planlama Teşkilatu (DPT) Destekli İleri Araşurma Projesi çerçevesinde hazırlanmışur.

\section{Osmanlı Maliyesinde Mukataa Sistemi ve Malikâne Uygulamasına Geçis}

"Mukataa" kavramı, "devlet işletmesi veya devlete ait bir gelir payının tahsili" anlamına gelmektedir. Devlet uygun gördüğü her türlü ziraî, ticarî ve sınaî kuruluşu mukataa haline getirebilir ve işi çoğunlukla özel teşebbüslere verirdi. Mukataaların başlarda "iltizam" ve "emanet" şeklinde işletilmeleri geleneksel bir uygulama idi. XVII. yüzyılın sonlarından itibaren "malikâne" sistemi de, mukataaların bir üçüncü işletme yöntemi olarak kullanılmaya başlanmışur.

${ }^{12}$ M. Cadırc1, aymı eser, s. 241. 
İltizam, “mukataaların müteşebbisler eliyle bir bedel karşıllğı işletilmesidir". Mukataa haline getirilen işletmenin vergi tahsil işi tahvil adı verilen üç yllık bir süre için açık arturma (müzayede) ile iltizama verilmekteydi. Daha sonraki süreçte savaş gibi durumlarda mukataaların, özellikle iltizam sistemiyle yönetilmesinde büyük zorluklar ortaya çıkmakta ve gelirlerde büyük dalgalanmalar olmaktaydı. Bir mukataanın iltizam süresi içinde bazen birkaç mültezime verilmesi, mukataa gelirlerinden faydalanmadan birçok masraflara katlanmış, harçlar ve resimler vermiş olan müteşebbisleri zora sokuyordu. Bu sebepten bazı mukataalar, rantabl olmadığından alıcısı da çıkmıyordu.

"Mukataalar, devlet eliyle bir memur kadrosu tarafindan işletilebilirdi". Bu durumda işletmeyi idare eden yönetici, devlet hazinesi tarafindan görevlendirilen ve emin adı verilen bir memur oluyordu. Görevi karşılığında devletten maaş veya dirlik alırdı. Genellikle mültezimlerin ilgisini çekmeyen, kazancı az görünen işletmeler emanet yoluyla işletilirdi. Havâss-ı Hümâyun denen ve devlete nakdî gelir sağlayan toprakların önemli bir kısmının gelirleri kethüda, voyvoda ve muhassil denen eminler tarafindan toplanırdı ${ }^{13}$.

Osmanlı maliyesinde ömür boyu verilen iltizama "malikâne" denirdi. İlk yıllarda malikâneler, sadece toprak olarak, devlet ve askerlik işlerinde başarı sağlayanlara verilmekteydi. Bu tip malikâne, özel mülk idi. Mirasçılara intikal ederdi. XVIII. yüzylda uygulanmaya başlayan sistem ise, mahiyet itibariyle farklıdır. XVI. ve XVII. yüzyllarda devlet hazinesinin artan nakit sorunu, nasıl tımarların iltizamlaşmasını ortaya çıkarmışsa, XVIII. yüzyılın hakim özelliklerinden biri de iltizamla işletilen mukataaların malikâneleşmesi olmuştur $^{14}$.

Malikânede, mukataaların gelirlerinin birer muaccele (peşin) ve her yıl ödenecek müeccele (taksit) karşılığında özel kesime satılması söz konusudur. 1683'te Osmanlı Devleti'nin II. Viyana yenilgisiyle başlayan sorunlu yllları, devlet hazinesini büyük malî sıkıntılarla karşı karşıya getirmiştir. Devlet malî bunalımlarına ve bütçe açıklarına çare bulabilmek amacıyla 1695 yı-

${ }^{13}$ Ahmet Tabakoğlu, Gerileme Dönemine Girerken Osmanl Maliyesi, İstanbul 1985, s. 122-129.

${ }^{14}$ Osmanh Devleti'nde malikâne uygulaması ve sonuçları üzerine daha ayrınulı bilgiler için bk. Mehmet Genç. "Osmanlı Maliyesinde Malikâne Sistemi", Osmanlı İmparatorluğunda Devlet ve Ekonomi, 2. Baskı, İstanbul 2002, s. 99-152; Murat Çizakça, İslam Dünyasında ve Bat 'da İ̧̧ Ortakları Tarihi, İstanbul 1999, s. 141-170; Erol Özvar, Osmanlı Maliyesinde Malikâne Uygulamass, İstanbul 2003. 
lında yayımladığı bir fermanla, mukataaların - vezir ve hanım sultanların hasları da dahil olarak - hayat kaydı (ber-vech-i te'bîd) şartı ile ilzam edilmelerini hayata geçirmiştir ${ }^{15} .12$ Ocak 1695 yilında yayınlanan bu fermanın belirttiği gibi ${ }^{16}$, bu sistemle öngörülen "sık sık değişen mültezimlerin mümkün olduğu kadar fazla kâr sağlamak uğruna tahrip ettiği vergi kaynağını ihya ve idame etmek üzerine değişmez bir mültezimin tasarrufuna bağlamaku" ${ }^{\prime 17}$. Bu şekilde 1695 'te başlayarak sonraki 100-150 ylllık malî sistem içinde bir müessese haline gelen malikâne uygulaması ${ }^{18}$, ilk olarak Şam, Halep, Diyarbakır, Mardin, Adana, Malatya, Ayıntab ve Tokat bölgelerinde uygulamaya konuldu.

Malikâne olarak satışa çıkarılan mukataaların, yıllık net kârlarının değerleri üzerinde açık arturma ile alınan "muaccele" (peşin satış bedeli), hazinenin yeni gelir kaynağıydı. Yani malikâne sahibi, satın aldığı mukataanın satıs tarihinde devlete temin etmekte olduğu ve "mal" adı verilen yıllık nakdî vergiyi ve bu verginin $\% 5$ ilâ 20 'si arasında kalem vs. teşkil eden harçlanını her sene üç taksit halinde ödemeyi taahhüt ediyordu ${ }^{19}$.

Malikâne uygulamasının ilk yıllarında reayaya da malikâneci olma firsat verilmişti. Ancak daha sonra 1714 'te bundan vazgeçildi. Çünkü malikâneye sahip olan müteşebbisin tasarruf hakkı sürekli kılınmasına rağmen, çoğu zaman reayalar, vergi konusunu korumaya dayalı siyasî güçten yoksun olduklarından, malikânelerini koruyamıyorlardı. Malikâne sisteminin en önemli sorunlarından birisi de, muaccelelerin şartlarının değişmesine karşın değişmezliği idi. Devlet bazen yeni düzenlemelerle muacceleleri artursa da, genellikle sabit görünen bir yekûn ortaya çıkmaktaydı. Ayrıca malikâneye sahip olan müteşebbisler, malikânelerin başında durmayarak, malikâneyi kendileri iltizama vermeye başladılar. Böylelikle malikâne sisteminde de, iltizam uygulaması gittikçe yaygınlaşmaya başladi ${ }^{20}$.

Osmanlı taşrasında malikâne olarak satşa çıkarılan mukataaların müzayedesinde peşin olarak yüklü bir para verilmesi söz konusu olduğundan, bu

${ }^{15}$ A. Tabakoğlu, aym eser, s. 130.

${ }^{16}$ Hatt-1 hümâyunun çıkıs tarihini Silahdar Mehmed Efendi, 12 Ocak 1695 olarak vermektedir. Yücel Özkaya, Osmanlı İmparatorluğu'nda Âyânlık, Ankara 1994, s. 107, dipnot 41.

${ }^{17}$ M. Genç, aynı eser, s. 105.

${ }^{18}$ Aynu eser, s. 105.

${ }^{19}$ Aymu eser, s. 108.

${ }^{20}$ A. Tabakoğlu, aym eser, s. 130-135. 
parayı ancak devlet ricalinden ve vilayet âyanlarından olanlar ödeyebilirlerdi. Bu bakımdan eyalet ve sancaklarda, açık arturmada malikâne mukataaların büyük bir kısmı, ileri gelen âyan, eşraf vb. gibi paralı kişilerin üzerinde kaldı. Böylece; has ve mukataat voyvodalıkları yoluyla bazı aileler zengin olup, zamanla nüfuz, güç ve zenginliklerini arturdılar. Bu da yeni başka sorunları beraberinde getirdi.

XVII. yüzylın ikinci yarısında ve XVIII. yüzyılın ilk yarısında mültezimlik yapan kimseler iyice zenginleşerek, mîrî mukataaları da malikâne olarak uhdelerine almaya başlamışlardır. Bu durum, XVIII. yüzylın ikinci yarısında Osmanlı ülkesinde bazı ailelerin daha da zenginleşmesine ve büyük güç kazanmalarına sebep olmuştur. Çünkü malikâneleri uzun yıllar idare eden aileler, büyük kârlar sağladıkları halde hazine bunlardan ölünceye kadar genellikle aynı vergiyi almak zorundaydı. Bunlar öldükten sonra, malikâneyi devlet bir başkasına yeniden kayd-ı hayat şartıyla satabilirdi.

XVIII. yüzyılda malikâne olarak idare edilen yerlerin sayıları devamlı artmış, bunun sonucunda Anadolu'da büyük hanedan aileler türemiştir. Bunlar güçlerini XIX. yüzyılın başlarında da devam ettirmekteydiler. Meselâ, Cabbarzâde Süleyman Bey, 1214 ilâ 1222 yılları arasında Tokat Voyvodalığı mukataasını malikâne olarak idare etmiş, bölgenin en etkin ve nüfuzlu kişisi olmuştur. Ömür boyu mukataa, sahibine hem süre güvencesi hem de kırsal ve kentsel topluluklarda saygınlık sağlayan bir vergi geliri denetim biçimi şeklinde tezahür ettiğinden ${ }^{21}$, Cabbarzâdeler gibi Anadolu'da diğer büyük aileler de bu güçlerini kullanma eğilimi içinde olmuşlardır.

XVIII. yüzyılın son çeyreğinde ve XIX. yüzyılın başlarında Anadolu'daki çoğu eyalet ve sancak, büyük hanedan ve âyanların yönetimine geçmiştir. Tokat gibi idare edilen bölgelerde de malikâne mukataalar, aynı dönemde bölgenin ayan ve eşrafindan olan voyvodalar vasıtasıyla yönetilmekteydi.

\section{Genel Olarak Tokat Voyvodalığı'nın Yapısı ve Voyvodalar}

18 Eylül 1659 'dan itibaren voyvodalık idarî-malî birimi içine sokulmuş olan Tokat, voyvodalar vasıtasıyla yönetilmeye başlanmışur ${ }^{22}$. Başlangıçta has denilen gelir bölgelerinin yönetimini sahibi adına yürüten kimseye voyvoda deniliyordu. Daha sonraları Tokat gibi bazı serbest umarların, vali ve muta-

${ }^{21}$ Dina Ruzk Khoury, Osmanlı Imparatorluğu'nda Deviet ve Taşra Toplumu, Musul, 1540 1834, İstanbul 1999, s. 107.

${ }^{22}$ E. Özvar, aynı tez, s. 37-38. 
sarrıflara verilen bazı gelirlerin de voyvoda gönderilerek yönetildiği görülmektedir. Tımar sisteminin XVII. yüzyıldan itibaren gittikçe bozulması ve iltizam usûlüne geçilmesi ve devletin para sıkıntusı çekmesi, geliri fazla bölgelerin doğrudan doğruya hazineye bağlanarak yönetilmesine yol açmış ve böylece voyvodalık kurumunun önemi artmıșur ${ }^{23}$. Diğer bir ifade ile, bir sancak has olarak verilmişse, yönetimi de voyvodalığa dönüştürülür ve has sahibi voyvoda tayin ederdi. Haslar sarayın ileri gelenlerine, özellikle sultanın yakın akrabalarnna verilmekte idi ${ }^{24}$.

12 Ocak 1695 yılında yayınlanan fermanla, Osmanlı maliyesinde mukataaların ömür boyu iltizama verilmesi süreci başlayınca, yani malikâne sistemine geçilmesiyle birlikte, en çok malikâne satışının yapıldığı bölgelerden biri de, Tokat Voyvodalığı olmuştur. Osmanlı Devleti'nde özellikle kırsal alanlardan toplanacak vergiler, kaza ya da nahiyelerin sınırlan içinde mukataalar yoluyla düzenlendiğinden, mukataalar da, o kaza ya da nahiyenin adıyla sistem içindeki yerini almıştur ${ }^{25}$.

XVIII. yüzyılın ikinci yarısından itibaren Osmanlı maliyesinde mukataalanın yine malikâne sauşı devam etmiştir. Bu dönemde bazı mîrî mukataaların yönetimi, Darbhâne-i Âmire'nin uhdesindeydi. Yüzylın ikinci yarısından sonra, Osmanlı malî örgütlenmesi içinde bazı değişikliklerle önemi artan, statü ve işlevinde bazı değişiklikler olan Darbhâne, ikinci bir devlet hazinesi gibi, devletin gelir ve giderlerinin yönetiminde görev üstlenen bir kurum durumuna gelmiştir. Özellikle 1773-74 yllarında bir ihtiyaç hazinesi biçiminde savaşların finansmanı için devreye sokulmuştur. 1787'den sonra Darbhâne, Hazine-i Âmire'nin giderlerine yardımcı ve ortak olmaya devam etmiş, III. Selim'in 1789 'da tahta geçmesinden sonra ise, sermaye akçesi yükseltilerek güçlendirilmiştir. Daha sonra Darbhâne'nin işlevlerini daha iyi yerine getirmek için, bazı gelir kaynakları bu kuruma bağlanmışur ${ }^{26}$. Bu bağlamda XVIII. yüzyılın son çeyreğinde Tokat Voyvodalığı mukataasının bazı hisseleri de, Darbhâne-i Âmire tarafindan yönetilmeye başlanmıştur.

${ }^{23}$ M. Cadirci, ayn eser, s. 29.

${ }^{24}$ Yücel Özkaya, Osmanlı İmparatorluğunda Ayânlık, Ankara 1994, s. 16.

251695 fermanından sonra, Tokat Voyvodalığı'ndan malikâne satulan kaza ve nahiyeler için bk. E. Ōzvar, Osmanlı Maliyesinde Malikâne Uygulaması, s. 97-98.

${ }^{26}$ Yavuz Cezar, Osmanlı Maliyesinde Bunalım ve Değişim Dönemi (XVIII. Yüzyıldan Tanzimat'a Mali Tarih), İstanbul 1986, s. 98-100. 
1773 yılında "Tokad Voyvodalığı ve tevâbi" mukāta'ası bâ-berât-ı âli-şân mutasarnfları tarafindan șartnâmesi mûcibince" Canik muhassılı ve Amasya mutasarrıfı Hacı Ali Paşa'ya Muharrem gurresinden/25 Mart'tan itibaren iltizam edilmiştir ${ }^{27}$. Tokat şer'iyye sicillerine göre, Tokat Voyvodalığı ve tevâbi mukataası üzerine 1773-1791 tarihleri arasındaki uygulamalar için çok aydınlatıcı veriler bulamadık. Ancak 09 Cemâziyülâhır 1211/10 Aralık 1796 tarihli bir fermana göre, 1205/1790-1791 ve 1206/1791-1792 senelerine mahsuben Tokat mukataasının voyvoda Yağcızâde Mehmed Bey’e iltizam edildiğini öğrenmekteyiz. "Suret-i defter mantûkınca ğayr-i ez havâlât ve teslîmât ve zimmet-i sahîhesi olan üçbin dörtyüz seksanyedi guruş Darbhâne-i Âmire'me müretteb olmağla" kaydı, adı geçen senelerde mukataa biriminin yine Darbhâne-i Âmire ile ilişkisinin olduğunu göstermektedir ${ }^{28}$.

14 Zilkade 1210/22 Mayss 1796 tarihli bir fermana göre, Tokat Voyvodalığı mukataası "ber-vech-i mâlikâne" III. Selim'in kız kardeşi Beyhan Sultan'In ${ }^{29}$ yönetimindeydi ${ }^{30}$. Sultan III. Selim, "seyyidetü' l-muhaddemât ekliletü'lmuhassenât tâcü' l-mestûrât zâtü' l-alî ve's-sa' dât hemşire-i muhteremem Beyhân Sultan dâmet ismetühâ ve zîdet iffetühânın ber-vech-i mâlikâne uhdesinde olan Tokad mukāta' ası" ifadesiyle voyvodalık biriminin malikâne olarak kız kardeşine bağlı olduğunu belirtmekteydii'. Yine 04 Rebiyülâhır 1216/14 Ağustos 1801 tarihli bir başka fermanda, Tokat Voyvodalığı mukataasının "ma' lûmü' l-mikdâr mâl ile sultân-ı müşârün-ileyhânı iştirâken bervech-i mâlikâne" uhdesinde olduğu kayıtlıydı. O halde mukataanın bütünü değil de, belirli hissesi Beyhan Sultan'ın yönetimindeydi ${ }^{32}$. Nitekim 28 Safer 1228/02 Mart 1813 tarihli bir başka fermandan, Beyhan Sultan'in "Tokad Voyvodalı̆̆ı mukāta'asından ber-vech-i mâlikâne ... rub" hissesinin bulunduğu ve müşterekleri hisseleriyle birlikte iltizama verildiği anlaşılmaktadır ${ }^{33}$.

${ }^{27}$ Canikli Ali Paşa'dan Tokat ileri gelenlerine yazılan Gurre-i Muharrem 1187/25 Mart 1773 tarihli buyruldu. TSS, 01, 212/2.

${ }^{28} T S S, 02,121$.

29 Beyhan Sultan, III. Mustafa'nın kızı, Sultan III. Selim'in kızkardeşidir. 02 Receb 1179/15 Aralık 1765 tarihinde Adilş̧ah Kadın'dan doğmuştur. I. Abdūlhamid tarafından Halep valisi eski Silahdar Mustafa Paşa ile 1784'de evlendirildi. 15 Rebiyülevvel 1240/07 Kasım 1824 öldū. M. Çağatay Uluçağ, Padişahlanın Kadınlan ve Kızlan, 2. Basku, Ankara 1985, s. 102-103.

${ }^{30} T$ TSS, 02, 68-69.

31 Aynu belge.

32 TSSS, 07, 62 .

${ }^{33} \mathrm{TSS}, 17,28 / 2$. 
Beyhan Sultan'in bu malikâne hissesi, III. Selim'in saltanat boyunca devam etmiștir ${ }^{34}$.

Sultan II. Mahmud yönetiminin başlarında da Beyhan Sultan, voyvodalık mukataasında malikâne hissesini tasarruf etmeyi sürdürmekteydi. Meselâ, 27 Muharrem 1223/25 Mart 1808 tarihli bir fermanda, "Voyvodalık-1 Tokad mukāta'ası ... serbestiyet üzere ... ma' lûmü' l-mikdâr mâl ve mu'accele ile sultân-1 müşârün-ileyhânm iştirâken ber-vech-i mâlikâne uhdesinde" olduğu belirtilmekteydi ${ }^{35}$.

19 Muharrem 1224/06 Mart 1809 tarihli bir fermana göre, "mukāta ât-ı mîrîyyeden Voyvodalık-ı Tokad ve tevâbi' mukāta 'ası"nın, "Darbhâne-i Âmire tarafindan zabt u idâre" ${ }^{36}$ edilmekte, 09 Safer 1224/26 Mart 1809 tarihli bir başka fermana göre de, Beyhan Sultan, "ber-vech-i mâlikâne", "serbestiyet üzere" voyvodalık birimindeki hissesini tasarruf etmeyi sürdürmekteydi ${ }^{37}$.

1811,1812 ve 1813 yıllarındaki kayıtlara göre, Tokat Voyvodalı̆ı ve tevâbi' mukataasının "nısf (1/2) hissesiyle nısf-ı südüs (yarımın 1/6'sı) hissesi" Darbhâne-i Âmire tarafindan zabt ve idare edilmekteydi ${ }^{38}$. 23 Safer 1228/25 Şubat 1813 tarihli bir buyrulduya göre, mukataanın gerek Darbhâne hissesi ve gerek Beyhan Sultan'ın rub' (1/4) hissesi, 1813 senesine mahsuben Sivas valisi İbrahim Paşa'ya iltizam edilmiş, paşa da Hacı Yusufzâde Yusuf Ağa'yı voyvoda tayin etmiştir ${ }^{39}$. Yani buradan anlaşılan mukataanın asıl sahibi Vali İbrahim Paşa'dır.

${ }^{34}$ 1771-1807 arası dỏnemde Tokat Voyvodalığı mukataasının Beyhan Sultan'ın uhdesinde bulunduğu ya da Darbhâne-i Âmire tarafından zabt u rabt edildiği üzerine şer'iyye sicillerindeki belgelerde herhangi bir ifadeye rastlanamamıştur. Ancak bu dönem arasında mukataanın yine Darbhâne-i Âmire tarafindan iltizama verildiği ve voyvodaların iltizam şartları gereği yōnetimi sağladıkları anlaşılmaktadır. Bu yıllar arasında mukataanın iltizama verilişi ve voyvoda isimleri için bk. TSSS, 01, 212/2; 01, 306; 01, 332; 02, 121; 02, 147/2; 03, 36; 03, 148/2;04, 15/1; 04, $107 / 1 ; 05,52 / 1 ; 06,65 ; 07,8$ ve $34 ; 07,36 / 1 ; 07$.

3527 Muharrem 1223/25 Mart 1808 tarihli ferman. TŞS, 11, 89. Yine 04 Safer 1223/01 Nisan 1808 tarihli bir başka fermanda da Sultan II. Mahmud, “...emmizâdem Beyhan Sultân ... ber-vech-i mâlikâne uhdesinde olan Tokad Voyodalığı mukāta' ası külliyetlü mâl ile mukayyed vâridât-ı cesîme-i mîrîyyemden olup" ifadesini kullanmaktadır. TȘS, 11, 90/1.

${ }^{36} T S S, 12,46 / 2$.

37 Fermanda Tokat ve tevâbi' mukataasının "nısf hissesiyle nısf-1 südüs an sümün hissesini "n Darbhâne-i Âmire tarafından zabt ve idare olunduğu belirtilmekteydi. TŞS, 12, 46/1.

${ }^{38} T S S, 14,38 / 2 ; 15,75 / 2 ; 16,37 / 2$.

39 Tokat kadısı, âyan, zabitler ve iş erlerine Sivas'tan gōnderilen buyruldu. TSS, 17, 29/1. Ayn konuda 09 Safer 1228/11 Subat 1813 (BOA, Cevdet Maliye, No. 21332) ve 28 Safer 1228/02 Mart 1813 tarihinde Beyhan Sultan'ın rub' hissesiyle, diğer hisselerin iltizam edildiğini hâvî fermanlar. $T S ̧ S, 17,28 / 2$. 
29 Muharrem 1234/28 Kasım 1818 tarihli bir fermana göre, Tokat Voyvodalığı mukataasının yarım hissesi Darbhâne-i Âmire, diğer yarım hissesi ise müşterekleri tasarrufundaydı. "Yed-i vâhidden" idare edilmek üzere, 1234 Muharremi gurresinden Zilhicce gâyetine/31 Ekim 1818 başından 19 Ekim 1819 sonuna değin bir seneliğine Voyvoda Derviş Ali'ye iltizam olunmuştur ${ }^{40}$.

1237/1822 senesinde Tokat Voyvodalığı mukataasının yarım hissesiyle rub $^{c}-1$ südüs (çeyreğin $1 / 6 \mathfrak{s} s$ ) hissesi Tokat voyvodası Hacı Ali Ağa'ya ihale edilmiş, ancak vefat ettiğinden aynı şartlar muvacehesinde voyvodalık iltizamı 64.271 kuruş mal, kalemiyye, harc-ı aklâm ve faiz mukabili Salih Ağa'ya iltizam olunmuştur ${ }^{41}$. Yine voyvodalığın yarım hissesiyle rub'-1 südüs ve rub'-1 sümün $(1 / 8)$ hissesinin, $1238 / 1823^{42}$ ve $1239 / 1824$ senelerine mahsuben 67.980 kuruş bedel-i iltizamla Salih Ağa'ya ihale edildiği görülmektedir ${ }^{43}$.

06 Cemâziyülâhır 1240/26 Ocak 1825 tarihli bir fermandan Tokat Voyvodalığı ve tevâbi' mukataasının yarım hissesiyle rub'-1 südüs (çeyreğin $1 / 6^{\prime} s 1$ ) ve rub' $(1 / 4)$ ve sümün (çeyreğin $1 / 8$ ) hissesi aynı yıla mahsuben yine 67.980 kuruş bedel-i iltizam ile hassa silahşörlerinden Süleyman Ağa'ya ihale edilmiştir ${ }^{44}$. Yine aynı tarihli Darbhâne-i Âmire nazırı Hacı Yusuf tarafından yazılan bir zabıtname kaydına göre, "Darbhâne-i Âmire'de Ceyb-i Hümâyûn-ı mülûkâne tarafindan zabt u idâre olınan mukāta' ât-1 mîrîyyeden Tokad Voyvodalı̆̆ı ve tevâbi' mukāta 'asının rub' hissesinin" Süleyman Ağa'ya ihale edildiği belirtilmektedir ${ }^{45}$.

Beyhan Sultan'ın voyvodalık mukataasında olan rub' hissesinin voyvodaya ihalesi hususunda yazdığı son zabıtnamesi, 04 Cemâziyülâhır 1239/05 Şubat 1824 tarihlidir. Mukataanın 1239/1824 Maru başından itibaren iltiza-

${ }^{40} T S S, 23,53 / 1$.

41 Zilkade 1237/07 Ağustos 1822 tarihli ferman. TŞ, 23, 59/1. 14 Ramazan 1083/03 Ocak 1673 tarihli bir arzda Tokat Voyvodalı̆ğ'nın 63.541 kuruşla Gürcũ Osman'a tevcih ve beraunın verilmesine dair kayıt mevcuttur. BOA, Cevdet Maliye, No. 22201.

4220 Rebiyūlâhır 1238/04 Ocak 1823 tarihli ferman. TŞS, 28, 20/1; Zabıtname için bk. TSSS, 28, 20/2.

4304 Cemâziyülevvel 1239/05 Şubat 1824 tarihli ferman, TŞS, 28,164/2; Zabıtname için bk. $T S S, 28,165 / 1$.

${ }^{44}$ TSS, 29, 95/2.

45 TSS, 29, 96/1. 
mını öngörmektedir ${ }^{46}$. Bu tarihten itibaren Tokat şer'iyye sicillerinde Beyhan Sultan'in voyvodalık mukataasındaki hissesi ile ilgili herhangi bir kayıt yoktur. Çünkü O, 07 Kasım 1824'de vefat ettiğinden malikâne hissesi Darbhâne tarafından nezaret edilmek üzere "Ceyb-i Hümâyûn-ı mülûkâne hazînesine" devredilmiştir ${ }^{47}$. Yukarıda belirtildiği gibi, 1825'de mukataanın yine "nısf hissesiyle rub'-1 südüs ve rub' ve sümün" hissesi Mart başından itibaren, Darbhâne tarafindan 67.980 kuruş ${ }^{48}$, Beyhan Sultan'dan Ceyb-i Hümâyun'a devredilen rub' (1/4) hisse de "sâbıkı misillü ellidörtbinyüz guruş bedel-i iltizâm ile" Tokat voyvodası hassa silahşörlerinden Süleyman'a ihale olunmuştur $^{49}$.

Diğer taraftan Osmanlı Devleti'nde 1813 yllında alınan bir kararla eyalet ve sancak dahilinde bulunan tüm mukataaların artuk yalnızca o bölgenin mülkî idarecilerine (vali, mutasarnf vb.) ihale olunması ilkesi kabul edilmiş ve uygulamaya geçilmiştir ${ }^{50}$. Bu kararın bir göstergesi olmalıdır ki, 1813 yllında Tokat Voyvodalığı mukataası da, Sivas valisi İbrahim Paşa'ya iltizam edilmiştir ${ }^{51}$. 1813'den 1817'ye kadar mukataanın ihalesi Sivas valilerine yapılmıs, bunlar da birimi yönetmek üzere buyruldu ile Tokat'a voyvoda atamışlardır. 1817 yılında ise, Sivas valisinin atadığı voyvoda Üveys Bey'in azliyle Tokat ahalisinin isteğine binaen merkezden Selanik Tütün Gümrüğü eski Emini Ali Ağa emaneten voyvoda atanmıs, $1818^{52}$ ve $1819^{53}$ yllarında ise, mukataa kendisine iltizam edilmiştir.

1245/1830'dan itibaren Tokat Voyvodalı̆̆ mukataası, "Mukāta' ât Haẑnesi ${ }^{5}$ tarafindan zabt $u$ idâre" edilmeye başlanmış ve aynı seneye mahsuben

461824 senesine mahsuben Beyhan Sultan tarafından voyvoda Salih Ağa'ya verilen sartnameyi ihtiva eden zabıtname kaydı. TSSS, 28, 165/1.

${ }^{47} T S S, 29,96 / 1$.

${ }^{48} T S S, 29,95 / 2$.

${ }^{49} T S S, 29,96 / 1$.

${ }^{50} 1813$ 'te bỏyle bir uygulamayla, hem halkın büyük kârlar peşinde koşan mültezimlerden korunması hem de gelirleri iyice düşmüş ve malî imkanları iyice azalmış mahallî idarecilerin biraz olsun kuvvetlenmesi amaçlanmışur. Bk. Y. Cezar, aymı eser, s. 242.

${ }^{51} T S S, 17,28 / 2$.

52 TSSS, 22, 52

${ }^{53} T S S, 23,53 / 1$.

543 Subat 1827 'de "Mukataat Nezâreti" adıyla yeni bir görev ihdas olundu ve Asâkir-i Mansûre'ye tahsis olunmuş olan tüm gelirlerin yōnetimi bu nazıra verildi. Nezaretin kurulması ile Hazine-i Âmire'nin bir şubesi olmaktan çıkan Mukataat Hazinesi, bağımsız bir hazine olmuştur. Mukataat Hazinesi ve Nezaretinin kuruluş ve gelişimi için bk. Y. Cezar, aynı eser, s. 252-262. 
sekiz hisseye ayrılarak, bunun beş sümün $(5 / 8)$ hissesi ${ }^{55}, 74.362$ kuruş bedel ile Halil Ağa'ya iltizam edilmiştir. İltizamı alan voyvoda, bu defa Mukataat Hazinesi'ne borç senedi (deyn temessükü) vermekle yükümlü tutulmuştur ${ }^{56}$. Ancak bir müddet sonra mukataa kendisinden alınarak, yine aynı yıla mahsuben Amasya sancağı mütesellimi dergâh-ı âlî kapıcıbaşılarından Hafiz Hasan'a ihale edilmiş, O da, dergâh-1 âlî gediklilerinden Muhammed Ağa'ya iltizam etmiştir ${ }^{57}$. Hafiz Hasan, 1831 ve 1832 yllarında da voyvodalık mukataasının asıl sahibi idi. 1834 yılında mukataa, Sivas valisi Hazinedarzâde Osman Paşa'ya "ber-vech-i muhassıllık" olarak verilmiştir ${ }^{58}$. Ancak bu uzun sürmemiş, kısa süre sonra mukataa, Amasya sancağı mütesellimi Ahmed Bey'e verilmiş̧ ${ }^{59}, \mathrm{O}$ da, hassa silahşörlerinden Latifzâde Hüseyin Ağa'ya iltizam etmiştirín.

1839 'da Tokat Voyvodalığı mukataasının Aınasya sancağı müteselliminin yönetiminde olduğu anlaşılmaktadır. "Dergâh-ı âlî kapucubaşılarından Amasya sancağı mütesellimi ve Tokad voyvodası izzetlü ağa" ifadesi bunu teyit etmektedir ${ }^{61}$. Tanzimat'la birlikte "Muhassıllık" malì birimi ihdas edilerek, Tokat'a da muhassıl atanmaya başlanmışur. Muhassıl, birimin malî işleriyle ilgili bir görevlisiydi. Yine Tanzimat'la birlikte Tokat Voyvodalığı'nın güvenlik işleri de, zaptiye memuruı un yönetimine verilmiştur.

\section{Tokat Voyvodahı̆ı Mukataasının İhalesi ve Birime Bağh Bazı Gelirler}

Tokat Voyvodalığı mukataası, mîrî mukataalar arasında büyük ve önemli bir yere sahipti. Nitekim bir belgede "Tokad Voyvodalığı mukāta'ası ...

${ }^{55}$ Belgede beş sümün hisse tabiri, 5/8'e tekabül eder. Mukatanın 5/8'i 74.362 kuruş bedel-i iltizam ile ihale olunduğuna göre, basit bir hesaplamayla herhalde sekiz hissenin tamam. da $118.479,5$ kuruş demektir.

${ }^{56} T S S, 35,10$.

${ }^{57} T S S, 35,88 / 1$.

58 TŞS. 38, 24. 21 Zilkade 1248 tarihli bir başka belgede, Trabzon valisi Osman Paşa, maiyyetindeki askerle birlikte Tokat'ta bulunmaktaydı. Ancak orada zahire tükendiğinden, Amasya'ya naklini istemiş ve gitmesine müsaade edilmiştir. Bu civarda isyan eden Mısır askeri olmadığı, bu sebepten muhafaza işlerini Amasya'dan yürüteceğine dair Osman Paşa'nın kaimesi ve irade için bk. BOA, Hatt-ı Hümayun, No. 20324; 20324 A, B, C.

${ }^{50} T$ SSS, 38, 142/2.

${ }^{60} T$ TSS, 39, 88/1.

${ }^{61} T S S, 52,66 / 1$. 
mukāta' ât-ı cesîme-i mîrîyyemde" ifadesi, adı geçen birimin büyüklüğünü, dolayısıyla önemini göstermektedir ${ }^{62}$.

Her yılın Mart ayından itibaren müzayede ile ihaleye çıkarılan voyvodalık mukataasını devlet hazinesine en yüksek yıllık vergi miktarını (muacceleyi) teklif ve tediye eden iltizama alıyor ${ }^{63}$, o da yönetimi sağlamak için bir voyvoda atıyordu. Mukataanın ihalesi, Darbhâne-i Âmire nazırının inhası üzerine, Dîvân-1 Hümâyun'un uygun görmesi sonucunda ferman ile gerçekleştirilmekteydi ${ }^{64}$. Ayrıca mukataayı alan şahsa, malikâne sahibi olarak sahip olduğu hak ve salahiyetleri ihtiva eden bir berat verilirdi. Devlet bu beratla, malikâneye ait olan vergi kaynağının bulunduğu alan ve mükellefler üzerinde her türlü malî haklarla birlikte bir kısım idarî ve inzibatî hakları da malikâne sahibine devrederdi ${ }^{65}$. Sonra mukataada hissesi olan malikâne sahibi Beyhan Sultan da (1824'e kadar), kendi hissesini yönetmek üzere voyvodaya "mâl-ı mîrî ve kalemiyyesiyle mahallinde virilecek vezâ'ifi vakt u zemânuyla edâ ve senedâtun" teslim eylemeyi hâvi zabıtname yazmaktaydı ${ }^{60}$.

Tokat Voyvodalığı mukataası nasıl iltizama veriliyordu? 1809 yllında yapılan bir iltizam fermanını inceleyerek bu soruya daha detaylı cevap bulmak mümkün olmaktadır. 19 Muharrem 1224/06 Mart 1809 tarihli bir fermana göre, Tokat Voyvodalığı ve tevâbi' mukataasının nısf hissesiyle nısf-ı südüs an sümün hissesi, 1224/1809 senesi Martundan itibaren bir ylllı̆̆ına "tâlib ve râgıb" olan Mehmed Behlül Bey'e, "mâl ve kalemiyye ve harc-ı aklâm ve kabz bedeli" 59.283 kuruş "bedel-i iltizâm" ile ihale edilmiştir. Behlül Bey de iltizamı aldıktan sonra, gerekli ödemeleri zamanında yapmak üzere Darbhâne-i Âmire hazinesine sarraf kefaletiyle mühürlü "deyn temessükü" vermiştir. Bu işlemler sonucu, Darbhâne nazırı Ahmed Şakir de, voyvodalığın yönetimi için emr-i şerif verilmesini inha etmiştir. Bu inhaya istinaden ferman yazılmış ve bu iltizam anlaşması kesinlik kazanmışur ${ }^{67}$. Ayrıca fermanda mukataa gelirlerine Behlül Bey dışında hiç kimsenin müdahale etmemesi ve voyvodanın

$62 T S ̧ S, 12,46 / 1$. Aynca bir fermanda "Tokad gibi belde-i azimenin" ifadesi de bunu teyit etmektedir. TSS, 11, 90/1.

${ }^{63}$ Erol Özvar, ayn tez, s. 40.

${ }^{6+1} T S S, 12,9 / 1$.

${ }^{65} \mathrm{M}$. Genç, aynı eser, s. 109.

${ }^{66} T S S, 12,47 / 1$.

${ }^{67} \mathrm{TSS}, 12,46 / 2$. 
ortaya çıkan "mahsûlât ve rüsûmâtı kānûn-ı kadîm ve olageldigi üzre ahz u kabz ve cem' u tahsîl" etmesi de yer almaktayd ${ }^{68}$.

Mukatanın "mu'tedil ve re' âyâ-perver kimesnelere der'uhde ve iltizâm" olunması ve malın her sene Hazîne-i Âmire, sebeb-i tahrir ve Rûznamçe-i Hümâyun temessükâtu gereğince havale olunan mahallere ödenmesi iltizam sartlarındand. Mukataanın fermanla verilmesinden sonra, Beyhan Sultan tarafindan da kendi hissesinin ihalesine yönelik voyvodalık şartnamesini hâvî zabıtnamesi yazılmışur ${ }^{\oplus \theta}$.

Osmanlı memleketlerinde mîrî mukataaları iltizama alanlar, uhdelerinde olan mukataatun "mâl irsâliyyelerini" Hazine-i Âmire'ye göndermekle yükümlüydüler. Ayrıca istenildiğinde havale olunan mahaller ile ocaklık ve vazife sahiplerine de ücretlerini ödemek zorundaydılar. Ayrıca mukataanın iltizam süresinin bitişinden sonra, "cânîb-i mîriçün hisâblarını rü'yet ve te'dîye-i zimmet eylemeleri düstûrü' l-amel tutulan şurût-1 mer 'iyyeden" idi ${ }^{70}$. Ancak bazen bu kurala uymayan iltizam sahipleri, mîrî malın eksilmesine sebep olabilmekteydiler. Meselâ, 05 Muharrem 1229/28 Aralı 1813 tarihli Tokat voyvodasına yazılan bir fermana göre, bir süreden beri mukataa iltizam edenler, "hisâb rü'yetine ri' âyet itmedüklerinden ber-mûcib-i kuyûdât zimmet-i sahîhe ve ğayr-i sahîheleri ma'lûm" olmadığından "vezâ' ifi olan mukāta'ât mâl irsâliyyelerinde sebeb-i tahrîr ahkâmı ve Rûznamçe-i Hümâyûn temessükâtı ile havâle olınan meblağ mikdârı zimmetimizde mâl-ı mîrî yokdur" deyip, havale edilmesi gereken meblağı ödemedikleri gibi, vazife sahiplerine de baskı yapmaya başlamışlardır. Bu sebepten mukataayı iltizam eden mültezimlerin zimmetlerinde, tahminen havale edilmesi gerekli meblağlar kadar mîrî mal birikmekteydi. Yazılan fermanla, mîrî mukataalardan vazife sahiplerine ödenmesi gereken meblağın, mukataaları tasarruf edenle-

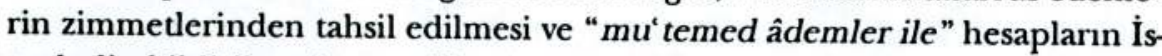
tanbul'a bildirilmesi emredilmekteydi. Ayrıca önemli mîrî mukataalardan olan Diyarbakır, Malatya ve Tokat voyvodalıları ile Haleb Muhassıllığı ve bunlara eş değer mîrî mukataa mallarından vazife havalesi denilerek, her sene büyük miktarda akçenin mîrî maldan düşüldüğü, ancak vazife sahiplerinin kimler olduğunun anlaşılamadığı, bu sebepten mukataa malından kimlere ne kadar ödeme yapıldı̆̆ı; havale olunan yerlerin adları, yazılış se-

\footnotetext{
${ }^{68}$ Aym ferman.

${ }^{69} T S S, 12,47 / 1$.

${ }^{70} T S S, 17,143$.
} 
bebi ve senedinin de gönderilmesi istenmekteydi. Ayrıca Tokat voyvodasına 76.531 kuruş 38 akçe mîrî malı olan Tokat Voyvodalığı ve tevâbi' malından da "mesârif-i mukarrere" denilerek 4.180 kuruşun düşüldüğü, ancak bu meblağın kimlere ödendiğinin kayıtlardan anlaşılamadı̆̆ı belirtilerek, geçmiş yllardan 1228/1813 yılı sonuna kadar "yedinde olan senedât-1 mîrîyyesiyle eshâb-ı vezâ'ifden ahz olınan zuhûrât ve sebeb-i tahrîr ahkâmını mu'temed" ederek İstanbul'a göndermesi ve hesabını da "ibrâ-yı zimmet" etmesi emredilmekteydi ${ }^{71}$.

02 Zilkade 1210/09 Mayss 1796 tarihli Tokat naibi ve Voyvoda Lütfullah ve Mübaşir İsmail'e hitaben yazılan bir fermandan, Tokat Voyvodalığı mukataasından hangi mahallere havalelcrin yapıldığı hususlarında malumat edinmek mümkün olmaktadır. Meselâ, 1209/1794 senesine mahsuben iltizamen Lütfullah Bey'e ihale edilen Tokat Voyvodalığı mukataasının 56.500 kuruş mîrî malından, 6.000 kuruşu İpeklizâde Mustafa Paşa'nın maaşına ${ }^{72}$, 10.000 kuruşu maaş taksiti olarak Hazine-i Âmire'ye, 10.000 kuruşu Tersâne-i Âmire masrafina, 27.971,5 kuruşu Tophâne-i Âmire kışlaklan için Darbhânei Âmire'ye ve 2.500 kuruşu da Vidin kalesi yeniçerilerinin ihtiyaçlarına havalesi ferman gereği zorunluydu. Ancak Hazîne-i Âmire'de tetkik edilen bir defter suretine göre, bu meblağlardan Tersâne-i Âmire masrafı için Darbhâne hesabına 10.000 kuruş, Tophâne-i Âmire kışlaklarının masrafı için de 7.971,5 kuruşun havale edildiği, Luna mukabil 20.000 kuruşun ve Vidin yeniçerilerine havalesi gereken 2.530 kuruşluk meblağın hiç ödenmediği anlaşılmışur. Bu bilgiler doğrultusunda bu işin çözümü için görevlendirilen mübaşire, Tokat'a varır varmaz kalan 22.530 kuruşun Voyvoda Lütfullah'tan alınarak havale eđtilmesini emreden ferman yazılmışur ${ }^{73}$.

XIX. yüzyılın başlarında Tokat Voyvodalığı mukataası gelirlerinin hangi kalemlerden oluştuğu ve nerelere harcama y..pıldığı hususunda şer'iye sicillerinde bilgiler mevcuttur. Aralık sonları 1814 tarihinde mukataa Sivas valisi Galip Mehmed Paşa'ya iltizam edilmiş, paşa da voyvodalığı emaneten yö-

${ }^{71}$ Aynu ferman.

7207 Rebiyülâhır 1209/01 Kasım 1794 tarihli bir fermana göre, Sivas'ta ikamete memur olan Mustafa Paşa, 'Tokad Voyvodalı̆̆ı mukāta' ası mâlından kendüye ma' âş olarak ta' yin olınan şehriyye beșer yüz guruşu" Voyvoda Lütfullah Ağa'nın kendisine vermediğini İstanbul'a yazmışur. Voyvoda, maaşı Mart sonuna kadar òdemiş, daha sonra zimmetinde mâl-ı mîrî kalmadığından ma'âş-ı mezkûrı edâ idemeyeceğini" bildirmiş, bu durumda Mustafa Paşa da, hakkının ödenmesini hâvî emr-i şerif yazılmasını istemiştir. Kayı ¿ardan yapılan incelemede Paşa'ya maaş mukabili havalenin yapılmasına yōnelik ferman yazılmışur. Bk. TŞS, 02, 59/1.

${ }^{73} T S S, 02,58 / 2$. 
netmek üzere hazinedarı Mehmed Ağa'yı Tokat'a voyvoda atamıştur ${ }^{74}$. Bu emanet görevi üç ay sürdükten sonra mukataanın ihalesi, 1815 Martından itibaren Tokatlı Üveys Bey'e yapılmıştır ${ }^{75}$. Sonrasında da halef-selef iki voyvoda arasında alacak-verecek ve devir teslim işlemini gösteren bir defter tertip edilmiş ${ }^{76}$ ve hesap kapatulmışur.

1695'te Tokat Voyvodalığı'ndan malikâne satılan kaza ve nahiyeler ile ${ }^{\pi}$, XVIII. yüzyılın son çeyreği ile XIX. yüzyılın ilk yarısında (Tanzimat'a kadar) malikâne verilen birimlerin aynı olup olmadığı konusunda Tokat şer'iye sicillerindeki belgelerde ayrıntılı bilgiler elde edemedik. Ancak Tablo I'deki Tokat Voyvodalığı mukataasının gelirleri ile ilgili veriler, Tokat kazası dahilindeki gelirleri; Tablo II'deki müfredât defterindeki bilgiler de daha çok Şarkipare, İlbeyli ve Sıraç kabilelerinin gelirleri, koyun kışlak harcı, bazı kazaların Beytülmalı vb. kapsayan gelirleri ihtiva etmektedir. $\mathrm{O}$ halde tablolara bakılarak, voyvodalık mukataasının voyvodalık birimi içinde daha dar bir gelir bölgesini kapsadığı anlamı çıkarılabilir. Yani Tokat Voyvodalığı mukataası, Tokat kazası ve nahiyeleri ile birlikte yakın bazı alanlarda malikâne olarak satılan mukataa gelirlerinin bir kısmını içermektedir. "Medîne-i Tokad voyvodası"78, "nefs-i Tokad kazâsı ve nevâhisi ahâlileri"79, Beyhan Sultan'ın "ber-vech-i mâlikâne uhdesinde olan Tokad kazâsı ve nevâhisi" ${ }^{0}$ ifadeleri, Tokat Voyvodalığı mukataasının Tokat kazası ve nahiyelerini kapsadığını göstermektedir. Ancak “Tokad Voyvodalığı kazâlarının kadıları ve nâ'ibleri"81 ifadesi, mukataanın sadece Tokat kazası ve nahiyeleriyle ilgili olmadığı, birime yakın bölgelerin bazı kaza gelirlerinin de bağlı olduğunu göstermektedir. Yine "Tokat ve Sivas sancaklarında vâki kazâların kadıları ve

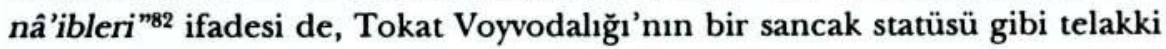
edildiğini düşündürebilir ${ }^{83}$.

${ }^{74} T S S, 19,105 / 1$.

${ }^{75}$ TSS, 19, 139.

${ }^{76}$ TSSS, 19, 146. Tokat Voyvodalığı mukataasına bağlı bazı gelir birimleri için bk. TABLO I ve TABLO II.

${ }^{77}$ Bk. E. Özvar, aym eser, s. 98.

${ }^{78} T S S, 10,2 / 1,2 / 2,2 / 3,2 / 4,2 / 8$.

${ }^{79} T$ TSS, 13, 98.

${ }^{80}$ TSS, 13, 108/3.

${ }^{81}$ TSS, 12, 73/1.

${ }^{82}$ TSS, $10,26$.

${ }^{83}$ Aslında Tokat, Sivas Eyaleti'nin Sivas Sancağı'na bağhı bir kaza statüsündeydi. 
O halde bilgileri toplarsak, XVIII. yüzyılın son çeyreği ile XIX. yüzyılın ilk yarısındaki Tokat Voyvodalığı'nın statüsü ile XVII. yüzyıldaki Sivas Eyaleti'nin Havâss-1 Hümâyun'a ait olan gelirlerinin yönetimi anlamma gelen ve malî bir birim olan Tokat Voyvodalığı, farkhı anlamlar içermektedir. Artuk XVIII. yüzyılın yeni şartları içinde Tokat Voyvodalığı mukataasından kastedilen, Tokat kazası ve nahiyeleri ile birlikte daha dar ve geliri yüksek bazı bölgelerin vergi gelirlerinin malikâne satuşıdır.

\section{Tokat Voyvodalannın Atanma ve Azilleri}

XVIII. yüzyılın sonları ile XIX. yüzyılın başlarında Tokat Voyvodalığı mukataası, yukanda da belirtildiği üzere, Darbhâne-i Âmire tarafindan zabt ve idare edilmekteydi. Mukataa "yed-i vâhidden" Darbhâne tarafindan iltizama verilebildiği gibi, Sivas valileri gibi devlet görevlilerine ihale olunduğunda, valiler adı geçen birimi "emaneten" yönetmek üzere buyruldu ile de bir voyvoda atayabilir ya da ikinci bir kişiye iltizam edebilirlerdi.

İncelediğimiz dönemde Tokat voyvodaları, mukataayı genellikle yed-i vâhidden, yani birinci elden iltizama almaktaydılar. Bunun yanında emaneten idare de söz konusu olmaktaydı. Meselâ, mukataa 1224/1809'da Mehmed Behlül Bey'e ${ }^{84}, 1225 / 1810^{\prime}$ da Ali Ağa'ya ${ }^{85}, 1227 / 1812^{86}$ ve 1228/1813'de ${ }^{87}$ Mehmed Salih Ağa'ya, 1234/1819'da Derviş Ali Ağa'ya “yed$i$ vâhidden zabt $u$ idâre olınmak üzere" iltizam olunmuştur ${ }^{88}$.

Tokat Voyvodalığı mukataasının emanetle yönetilmesi işlemi konusunda da birkaç örnek verilebilir: Meselâ, 1222/1807'te Tokat Voyvodalığı mukataası Bozok mutasarrıfı Cabbarzâde Süleyman Bey'e ihale olunmuştur. Mutasarrıf da, "tarafından" İlbaşıŏlu Ahmed Ağa'yı "voyvoda nasb u ta'yîn" etmiştir ${ }^{89}$. 1228/1813 yılına mahsuben voyvodalık mukataası, Sivas valisi İbrahim Paşa'ya ihale edilmiş, vali de buyruldu ile Erzurumlu Hacı Yusufu voyvoda atamışur ${ }^{90}$. Yine 1815 yilında voyvodalık mukataası, Sivas valisi Galip Mehmed Paşa'ya ihale edilmiş, $O$ da, hazinedarı Mehmed Ali Ağa'yı Tokat'a

\footnotetext{
${ }^{81} T S S, 12,46 / 2$.

${ }^{85}$ TSS, $14,138 / 3$.

${ }^{86} \mathrm{TSS}, 15,75 / 2$.

${ }^{87}$ TSS, 17, 27.

${ }^{88}$ TSSS, 23, 53/1.

${ }^{89}$ TSS, $11,90 / 2$.

${ }^{90} T S S, 17,28 / 2$.
} 
"ber-vech-i emânet" voyvoda atamışur ${ }^{91}$. 1231/1816 ve 1232/1817 yillarında Tokat Voyvodalığı mukataası, bu defa Sivas valisi Osman Paşa'ya ihale edilmiş, O da, 1816 yılı için emaneten Abdüllatifzâde Hüseyin Ağa'yı voyvoda atamışur ${ }^{92}$.

Şimdi Tokat voyvodalarının atanma ve azilleri ile ilgili daha detaylı bilgiler vermek için, belgeleri incelemek istiyoruz:

Tokat Voyvodalı̆ı ve tevâbi' mukataasını iltizama alan mültezim, anlaşma şartlarına aykırı herhangi bir kanunsuzluğa sebep olduğunda, iltizam mukavelesi feshedilerek, aynı şartlarda başka birine ihale söz konusu olurdu. Meselâ, 1222/1807 senesine mahsuben "Tokad Voyvodalığı mukāta'ası" Abdülcabbarzâde (Cabbarzâde) Süleyman Bey'e iltizam olunmuş, O da, mukataayı yönetmek üzere İlbaşığlu Küçük Ahmed Ağa'yı voyvoda atamıştur. Ancak voyvodanın "memleketi tecrîm iderek külliyetlü şey ahz eyledigi ahâli tarafindan" arzuhal, mahzar ve ilâmla İstanbul'a bildirilince, "mukāta'a-i merkūm iltizâmı mûmâ-ileyhin uhdesinden fekk" olunmuştur. Daha sonra voyvodalık mukataası, "mâl-1 mîrî ve kalemiyyeleri ve ashâb-1 mâlikânenin fâ'izlerini mahallerine" zamanında ödemek şartıyla Mehmed Metin'in "uhdesine ihâlesi tanzîm" olunmuş, eski mültezim Süleyman Bey'in de mukataa malından aynı yıl için bir akçe talep etmemesi hususunda anlaşma sağlanmışur. Ancak Süleyman Bey, "sene-i mezkûreye mahsûben ba'zı mahallere ubûdiyyet ve avâ' id nâmıyla virdiği akçeyi halefi voyvoda-i mûmâ-ileyhden mütâlebe ve tazyîk" edince, bu davranışın "şurût-ı mu'âhedenin hilâfi" olduğu, bu sebepten "akçe mütâlebesiyle vâki' olan müdâhalenin men' ü def içün" Beyhan Sultan'ın kethüdası Ahmed Azmi Efendi emr-i şerif verilmesini istemiştir ${ }^{93}$.

Sorunun halli için başmuhasebe kayıtlarına başvurulmuştur. Yapılan araşurmada "voyvodalık-ı mezbûrın mûmâ-ileyh Mehmed Metin zîde mecduhûnın uhdesine ihâle vü iltizâm" olunduğu anlaşılmıştur. Bu bilgi ve kethüdanın inhasına istinaden Tokat naibine 09 Safer 1223/06 Nisan 1808 tarihinde bu ferman yazılarak, Süleyman Bey'in müdahalesinin önlenmesi ve emirlere aykırı hareketlerden kaçımılması emredilmiştir. Ayrıca Voyvoda Mehmed Metin'e de şu emirler verilmiştir: "Sen ki voyvoda-i mûmâ-ileyhsin tarafindan o makūle avâ' id nâmı ve nâm-ı âhar ile mûmâ-ileyh cânibine

${ }^{91} T$ SSS, 19, 105/1.

92 TSS, $20,49$.

${ }^{93}$ TSS, 11, 90/2. 
nesne virilmesi iktizâ itmemekle o makūle ta'addîsine havâle sem 'î ve i' tibâr olınmayup hemen mûcib-i ta' ahhüdün üzre mâl-ı mîrî ve kalemiyye ve ashâb1 mâlikânenin fâ'izlerini edâ ve himâyet-i fukarâ husûsına dikkat ü i' tinâ eylemek bâbında fermân-ı âli-şânım sâdır olmışdur"mit. O halde Tokat mukataası iltizamını uhdelerine alan mültezimler, ihale şartlarına aykırı hareket ettiklerinde ya da halka zulüm yaptıklarında anlaşmaları feshedilerek, aynı şartlarda bir başkasına ihale söz konusu oluyordu.

Tokat Voyvodalığı mukataasını uhdesine alan mültezim, vefat ettiğinde voyvodalık yine aynı şartlarda bir başkasına ihale edilebilirdi. Meselâ, $25 \mathrm{Re}$ ceb 1223/16 Eylül 1808 tarihli bir fermana göre, aynı yıl için "Tokad Voyvodalığı mukāta' ası ... iltizâmen uhdesine ihâle olınan silahşörân Mehmed Metin bu esnâda vefât" ettiğinden, mukataa müddetini tamamlamak ve adı geçen senenin Şubat sonuna değin "mukāta'a-i mezbûrın kâffe-i â' îdât u müktesâbâtımı cem' u tahsîl ve sene hitâmına dek ne hâsıl olur ise mümzâ ve mahtûm defterini irsâl eylemek üzere Tokad voyvodası mûmâ-ileyh Mustafa" Ağa'ya ihale olunmuștur ${ }^{95}$.

Tokat Voyvodalığı mukataası iltizamı, bazı durumlarda hiçbir sebep gösterilmeden sahibinden alınarak bir başkasına verilebilirdi. Meselâ, 22 Safer 1228/24 Şubat 1813 tarihli bir belgeye göre, Tokat Voyvodalığı ve tevâbi mukataasının yarım hissesiyle nısf-ı südüs hissesi, 1813 senesine mahsuben Mehmed Salih Ağa'ya iltizam olunmuş ve bu hususta emr-i şerif yazılmıştur. Ancak "hasbe'l-iktizâ" adı geçen mültezimden alınarak, 1813 senesi Martundan itibaren Erzurumlu Hacı Yusufzâde Yusuf a 64.000 kuruş bedel-i iltizam ile verilmiştir ${ }^{96}$.

Yine bu iltizama yönelik Sivas valisi İbrahim Paşa, İstanbul'a yazdığı bir takriri ile Beyhan Sultan'ın Tokat Voyvodalığı mu' . sesiyle şürekâ-i sâ' ire hisseleri yed-i vâhidden zabt u idâre olınmak üzere" 1813 senesine mahsuben Beyhan Sultan'ın verdiği şartnameye istinaden kendisine iltizam olunduğunu, kendisinin de mukataayı yönetmek üzere Er-

94 Ayni ferman.

95 Bu ferman, Beyhan Sultan'ın kethüdası Ahmed Azmi'nin, voyvodahğın bütün aidat ve hasılatunın eskiden olduğu gibi serbestiyet üzere zabt ettirilmesi, "mâl-ı mukāta'a tekmîl olmadukca âhar mahallere bir akçe ve bir habbe virilmemesi" hususuna dikkat edilmesi ve mîrî emvalin telefinden kaçınılması hususlarını belirten takririne istinaden yazılmıştur. TŞS, 12, 9/1. Ayrıca bu fermana istinaden Tokat naibi, Voyvoda Seyyid Mustafa Ağa, vūcûh-1 memleket ve iş erlerine Sivas valisinden bir buyruldu yazılmıştur. TSSS, 12, 9/2.

96 TSS, 17, 27. 
zurumlu Yusuf Ağa'yı buyruldu ${ }^{97}$ ile voyvoda atadığını belirtmiştir. "Bedel-i iltizâmlar içün iktizâ iden mebâliğ vakt $u$ zamâniyle edâ itmek üzere voyvodai mûmâ-ileyhin" İstanbul'da olan sarrafinın kefaletiyle sultana temessük verildiğini de belirten Paşa, "sultân-ı müşârün-ileyhâ ve şürekâ-i sâ' irelerin" yönetimine kimsenin müdahale etmemesini belirten hasseten bir emr-i şerif verilmesini istemiştir. Bu takrire istinaden 28 Safer 1228/30 Şubat 1813 tarihinde "sultân-ı müşârün-ileyhânın uhdesinde olan rub' hissesiyle şürekâ-i sâ'irelerinin hisselerini sene-i mezbûr Martı ibtidâsından Şubatı gâyetine degin bir sene-i kâmile yed-i vâhidden voyvoda-i mûmâ-ileyh tarafindan zabt u rabt" olunmasını belirten ferman yazılmıştır ${ }^{98}$.

Yusuf Ağa bir yıl sonra voyvodalıktan azledilmiştir. Sivas valisi İbrahim Paşa, Tokat ileri gelenlerine 13 Safer 1229/14 Şubat 1814 tarihli bir buyruldusu ile "eyâlet-i Sivas dâhilinde beldeniz voyvodası hâssa silahşörânından Yusuf Ağa'nın azl olınup yerine ra'iyye-perver ve munsif ve mu'tedil ve kâr âşinâ voyvoda nasb u ta 'yin olınmasını" halkın kendisinden rica ettiklerini, bu istekler çerçevesinde kapı halkı eski emekdarlarından silahdarı Gürcüzâde Mehmed Ağa'yı voyvoda atadığını bildirmiştir. Paşa, atama işleminden sonra, Mehmed Ağa'ya görevini doğru dürüst bir biçimde yapması, halkı koruması ve aykırı hareketlerde bulunmaması konusunda ayrıca uyarılarda bulunmuştur ${ }^{99}$.

27 Rebiyülevvel 1230/09 Mart 1815 tarihli bir buyrulduya göre, Tokat Voyvodalı̆̆ı mukataası bu defa Sivas valisi Mehmed Galip Paşa'ya ihale olunmuş, paşa da Mart sonuna değin mukataayı "ber-vech-i emânet" yönetmek üzere hazinedarı Mehmed Ali Ağa'yı Tokat voyvodası tayin etmiştir ${ }^{100}$. Ancak Galip Paşa ${ }^{101}$, voyvodalığa atadığı hazinedarını "hasbe'l-maslahat mahall-i âhara" başka bir göreve atadığından, mukataayı "Tokad hânedânından" Seyyid Hacı Üveys Bey'e iltizam etmiştir ${ }^{102}$. Ancak mukatanın asıl sahibi, Sivas valisi Mehmed Galip Paşa'dır.

9723 Safer 1228/25 Şubat 1813 tarihli Sivas valisi İbrahim Paşa'nın Tokat kadısı, âyan, zabitan ve iş erlerine hitaben gönderdiği buyruldu. TŞS, 17, 29/1.

${ }^{98} T S S, 17,28 / 2$.

${ }^{99}$ Bu buyruldu Tokat naibi, voyvoda Mehmed Ağa, nakibüleşraf vekili, serdar, ağalar, iş erlerine hitaben yazilmıştur. $T S ̧ S, 18,79 / 1$.

${ }^{100} T S S, 19,105 / 1$.

10104 Rebiyülâhır 1230/16 Mart 1815 tarihli Tokat Voyvodalığı zabuna müteallik emr-i âli. $T S S S, 20,174 / 2$. Bu hususta Beyhan Sultan'ın zabıtnamesi de vardır. $T S ̧ S, 20,174 / 1$.

102 Galip Paşa, Üveys Bey ve Tokat ileri gelenlerine hitaben "vedî' atullâh olan fukarâ vü zu'afâ ve re' âyâ vü berâyânın âsâyiş ü emniyetle himâyeti ve bi'l-husûs ahkâm-ı şerĩ ât-ı 
Yine voyvodalık mukataasımın emanetle yönetimine bir örnek için, 21 Rebiyülâhır 1231/21 Mart 1816 tarihli buyrulduyu incelemek gerekir. 1816 yılında Tokat Voyvodalığı mukataası, "bâ-şartnâme" Sivas valisi Osman Paşa'ya ihale olunmuştur. Ancak eyalet, bu dönemde paşanın atadığı mütesellim Hüseyin Ağa tarafından yönetilmektedir. "Voyvodası hîn-i vürûdına değin", voyvodalığa "â' id ve râci" îrâd ve tayyârât bi' l-emâne veya defter-i hıfz ve himâye ve ahz u kabz"ını yürütmek üzere, Sivas mütesellimi tarafindan, "Tokad eşref hanedânından ve evsâf-ı mezkûrelerle mevsûf" Abdüllatifzâde Hüseyin Ağa voyvoda atanmışur ${ }^{103}$.

Tokat Voyvodalı̆̆ı mukataasını yöneten voyvodalar, eğer görevlerinde başarılı iseler ya da halkla iyi geçinmişlerse, daha sonraki yllarda da bu göreve getirilebilirlerdi ${ }^{104}$. Meselâ, 05 Zilkade 1231/29 Eylül 1816 tarihli bir belgeye göre, Tokat Voyvodalı̆̆ı mukataası, yukarıda da ifade edildiği gibi, Sivas valisi Osman Paşa'ya ${ }^{105}$ ihale olunmuştur. Paşa da mukataaya sahip olduktan sonra, birimi kendi adına emanetle yöneten Hüseyin Ağa'nın yerine Üveys Bey'e iltizama vermiştir. Osman Paşa; Tokat naibi, Voyvoda Üveys Bey ve ileri gelenlere yazdığı buyrulduda, mukataanın "umûr-ı voyvodalığına müdîr ve muktedir ve munsif birinin voyvoda nasbı lâ-büdd" olduğunu belirterek, "öteden berü kâr-güzâr ve fukarâ ve re'âyâ-perver" olması nedeniyle Üveys Bey'i voyvodalığa atadığını bildirmiştir ${ }^{106}$. Osman Paşa, Voyvoda Üveys Bey'den memnun olmalıdır ki, 11 Rebiyülâhır 1232/28 Şubat 1817 tarihli bir başka buyruldusuyla, mukatanın yönetimini 1817 senesine mahsuben de Voyvoda Üveys Bey'de bırakmıștur. Nitekim buyruldusunda "Tokad' in hânedân ve hânmân-ı kadîmi" olan Üveys Bey'in voyvodalığı süresince "umûr-ı mehâmın rü'yetiyle sıdk-ı istikâmeti zâhir olmış ve ahâli ile hüsn-i imtizâc iderek vedî̃ a-i cenâb-1 kibriyâ olan fukarâ-yı ra iyyeti sıyânet idegeldigi"ni belirten Paşa, "haklarında hüsn-i teveccüh-i kâmilemiz" malumdur diyerek bu atamayı yaptı̆̆ını belirtmiştir. Atama işleminden sonra Osman Paşa; Tokad kadısı, ağalar, zabitler ve iş erlerine "mîr-i mûmâ-ileyhi voyvoda bilüp her bir

mutaharranun ke-mâhîye-hakkuhâ icrâsı olmağla bu dakikalara cümlenin bi'l-ittifâk ihtimâm ve gayret" gösterilmesini istemekteydi. T\$̧S, 19, 139.

${ }^{103}$ Sivas Eyaleti mütesellimi İbrahim'den gelen buyruldu. TŞS, 20, 49.

104 Tokat Voyvodalığı ve tevâbi' mukataası bir yıllı̆̆ına ihaleye verilmekteydi. Ancak memnunluk hasıl olursa, diğer yllarda da aynı kişiye iltizam edilebilirdi.

105 Osman Paşa, Evâil-i Şevval 1231/Ağustos sonu-Eylül bașı 1916'da Sivas Eyaleti valiliğine getirilmiştir. $T S \$ S, 21,127$. Daha sonra Tokat mukataası iltizamı da uhdesine verilmiştir. $T S S S, 20$. 49.

${ }^{106} T$ TSS, 21, 182. 
re'y ve irâdesine mutâva'at ve umûr-1 voyvodalığına efrâd-1 efrîdeden hiç bir ferd müdâhale eylemeyüp merâsim-i ittifâkiyye mübâderet ve hüsn-i mu'âşerete" uyulmasını, voyvodaya "kendüni voyvoda bilüp işbu sene-i merkūma mahsûben zabt u rabt ve rüsûmât-1 kadîmini cem 'ü tahsîl eyleyüp her bir etvâr ve harekâtunızı nehc-i şer'-i şerîf ve kānûn-ı münîfe tatbîk eyleyerek def ü ref' erbâb-1 şurûr u mefsedet ve derûn-1 beldede vukû‘ bulan mevâddan ifâdesi lâ-büdd ve müktezî olan husûsâtun bâ-i' lâm-1 şer 'iyye" tarafina yazılmasını, "eşkıyâya ruhsat ve meydân" verilmemesini, halkın emniyet ve rahatının sağlanmasını emretmiştir. Paşa, ayrıca voyvodalığını tebrik etmek için, Üveys Bey'e voyvodalık nişanesi olarak “bedĩa samûr ferve” elbise göndermiştir ${ }^{107}$.

\section{Tokat Voyvodalannin Görev ve Yetkileri}

Tokat voyvodalan, hem Tokat Voyvodalığı ve tevâbi‘ mukataasından sorumlu malî bir tahsildar, hem de sancakbeyi yetkilerine haiz idarî, askerî, inzibatî vs. görevleri uhdesinde toplayan bir görevliydi. Tokat voyvodalarının yetki ve sorumluluklarına bakıldığında bu durum daha açık bir biçimde ortaya çıkar.

Tokat voyvodaları; Tokat kazası, nahiyeleri ve köylerindeki voyvodalık mukataasına bağlı gelirleri yönetirlerken, ortaya çıkan güvenlik sorunlarında ve ya da reayaya karşı tasallut ve rencide ortaya çıktığında, Tokat kadısı ya da naipleri ile birlikte suçluları cezalandırırlardı. Cezalandırma, “voyvodalarının ma'rûf olan tezkeresi ve hâkîm-i beldenin mürâselesi ile icrâ” olunmakta idi. Voyvodaların tezkeresi olmadıkça sadece hakim mürâselesiyle suçluların cezalandırılmaları söz konusu değildi ${ }^{108}$.

Tokat'ta, İslamî uygulamalara aykırı durumlar ortaya çıkuğından bunu önlemek, diğer görevlilerle birlikte voyvodaların da görevleri arasındaydı. Meselâ, 11 Safer 1224/28 Mart 1809 tarihli bir emirnameye göre, sadrazamlığa atanan Yusuf Ziya Paşa, görevi devralmak için İstanbul'a giderken Tokat'tan geçmiş ve bazı İslam ahalinin, kiracısı zımmîler ile beraber bir hanede oturduğunu haber almıştur. Sadrazam, bu durumun önlenmesi için, Tokat kadısı, voyvodası, vücûh-ı memleket, yeniçeri serdarı ve ocaklı ağavâtuna " $O$

107 Sivas valisi Osman Paşa tarafından mühürdarı Hüseyin Hulusi ile Üveys Bey'in voyvodalı̆̆ını hâvî Tokat ileri gelenlerine gõnderilen buyruldu. TŞS, 21, 66-67.

1084 Safer 1223/1 Nisan 1808 tarihli Tokat naibi, Tokad voyvodası Metin Mehmed ve kale dizdanna hitaben yazılan ferman, TS\$S, 11, 90/1. 
makūle ehl-i İslâm ile bir hânede mütemekkin olan zımmî tâ' ifelerini teftîş ve taharrî eyleyerek ma'rifet-i şer'-i şerîf ve voyvodası ağa ve sâ' ir muhâtabûn ma' rifetleriyle ihrâc ve zımmîyâna mahsûs olan hânelerde iskân" ettirilmelerini emretmiştir ${ }^{109}$. Burada görüldüğü gibi, voyvodalar, dinî ve sosyal bir görevin yerine getirilmesinden de sorumluydu.

Öte yandan gayr-i Müslimler tarafindan ibadet yerlerinin tamiri konusunda İstanbul'a arzuhal yazıldığında, mahallinde emredilen işlemleri yerine getirme işlemleri yine kadı ve voyvodanın nezaretinde yapılmaktaydı. Meselâ, Evasıt-1 Zilkade 1219/Şubat ortaları 1805 tarihli bir fermana göre, Tokat'ta Yahudiler, Rikâb-1 Hümâyun'a arzuhal yazarak Sinadnik'lerinin tamire muhtaç olduğunu ve buna izin verilmesini istemişlerdir. İstanbul'dan Tokat naibi ve voyvodasına, eğer ibadet mekanı ve civan harabe ise, asliyesine göre ek bir ilave olmaksızın tamir ettirilmesi, bu bahane ile ilgililerden hiçbir akçe alınmaması emredilmiştir ${ }^{110}$.

Rusûm-1 zecriyye gibi vergi konusunda ortaya çıkan sorunlarda da voyvodaya görev verilebilmekteydi. Meselâ, 26 Safer 1224/12 Nisan 1809 tarihli bir fermana göre, Tokat kazasının rüsûm-ı zecriyyesi 3.000 kuruş idi ve her sene Ağustos ayı başında ödenmekteydi. Ancak 1808, yılına mahsuben bu meblağ ödenmemiş ve reayanın zimmetlerinde kalmıştur. Bu meblağın, 300 kuruş tutan mübaşir ücreti ile birlikte toplanması ve hazineye gönderilmek üzere mübaşire teslimi görevi; vücûh-ı memleket, iş erleri ile birlikte Tokat voyvodasına verilmiştiri"11. Yine aynı konudaki bir başka fermana göre, voyvodaya hitaben "sen ki voyvoda-i mümâ-ileyhsin ... sene-i merkūma mahsûben mukayyed olan mârü' z-zikr üçbin guruş rüsûm-ı zecriyyesi ma 'rifetin ve kādi-i mûmâ-ileyh ve mübâşir-i merkūm mầ rifetleriyle yerlü yerinden ve icâb ve iktizâ idenlerden temâmen ve kâmilen tahsîl ve kabzına me'mûr mübâşirine" teslim etmesi emredilmekteydi ${ }^{112}$.

Tokat voyvodaları, Tokat kazasının asayişinden de sorumlu idiler. Kazada suç işleyen kişilerin cezalarının mahkeme vasıtasıyla verilmesinden sonra, yerine getirilmesi için voyvodaya mahkemeden mürâseleler yazılmaktaydı. Meselâ, 1806 yılında Tokat kazasından bazılarına galiz küfürler eden Mustafa Alemdarınoğlu Seyyid Mehmed'in, mahkemece verilen cezasını

${ }^{109} \mathrm{TSS}, 12,49 / 1$.

${ }^{110} \mathrm{TS} S, 10,29 / 2$.

$111 \mathrm{TSS}, 12 / 54$.

112 TŞS, $12 / 55 / 1$. 
çekmek için kaleye intikali ${ }^{113}$, hırsızlık hususunda mahkemenin verdiği karara göre suçluyu "te' dîb" etmek ${ }^{114}$ ve Seyyid Ahmed ile dört arkadaşının avret kapısına gittiklerinden mahkemece verilen " $t a$ ' zîr" cezasının zabitleri vasıtasıyla yerine getirilmesi ${ }^{115}$ hususunda Tokat voyvodası Seyyid Ahmed Ağa'ya mürâseleler yazılmış ve görevleri yerine getirmesi istenmiştir.

Tokat voyvodası, kendisine verilen askerî görevleri de yerine getirirdi. Meselâ, Evasıt-1 Safer 1223/Nisan ortaları 1808 tarihinde gönderilen bir fermana göre, Rusya ile ortaya çıkan savaş sebebiyle daha önce Tokat kazasından başbuğlan maiyyetinde yüz elli adet asker istendiği, ancak bu askerlerin henüz gönderilmediği, tehir edilmeyerek acilen askerin ordu-yı hümâyûna ulaşurılması istenmektedir. Bu askerlerin tertip edilmesi ve gönderilmesi emri Tokat naibi ve voyvodaya hitaben yazılmışur ${ }^{116}$.

Tokat menzilhanesinin devamlı surette nizam ve intizam içinde bulunması, gelip giden ulakların görevlerinin düzenli bir biçimde gerçekleştirmelerine yardımcı olmaları hususunda Sivas'tan gelen buyrulduların muhataplarından birisi de, Tokat voyvodası idi. Yani, gerek Payitaht ve gerekse diğer eyalet ve sancaklarla haberleşmenin sağlanmasını kolaylaşturacak önlemleri alma da, Tokat voyvodasının görevleri arasındayd ${ }^{117}$.

Sonuç olarak söylemek gerekirse, Tokat voyvodalarının sadece Tokat Voyvodalığı mukataasındaki malî işlemleri yürüten bir görevli olmadığı, idarî, askerî sosyal ve inzibatî işlerle ilgili görevler de üstlendiği ortaya çıkmaktadır.

\section{Tokat Voyvodalı̆̆ı Mukataasına Müdahaleler}

Beyhan Sultan'ın "ber-vech-i mâlikâne uhdesinde olan voyvodalık-ı Tokad mukāta'ası öteden berü serbestiyet üzere zabt u rabt" olunduğundan, voyvoda dışında "kimesne tarafindan müdâhale ve ta'arruz iktizâ itmez" idi ${ }^{118}$. Ancak bu nizama rağmen, voyvodalık mukataasına birçok defalar vali, mütesellim, mutasarrıf vb. gibi ehl-i örf mensuplarının müdahaleleri eksik

\footnotetext{
113 TŞS, 10, 2/1.

114 TŞS, $10,2 / 2$.

115 TŞS, 10, 2/7.

$116 \mathrm{TSS}, 11,95 / 2$.

117 TSS, 3, 7/1.

118 TSS, 11, 89.
} 
olmamıştur. Meselâ, Kasım 1803 tarihli bir fermana göre, Beyhan Sultan'ın malikânesi olan Tokat ve bağlı yerler mukataasına Sivas valisi müdahalelerde bulunarak, halktan kaftan-bahâ, ikramiye, devriye vb. adlar altunda fazla para talep etmekte ve halkı zor duruma sokmaktaydı. Bu sorunun çözümü için bölgeye mübaşir gönderilmiş ve kanunlara aykırı olarak mukataaya bağlı halktan talep edilen akçe, emtia vb. şeylerin, hak sahiplerine iade edilmesi istenmiştir. Ayrıca emirlere karşı gelen, kanun ve uygulamalar dışında hareket eden görevlilere şiddetli uyarılar yapılarak, kanunsuzluğa tevessül etmemeleri emredilmiştir ${ }^{119}$.

27 Muharrem 1223/25 Mart 1808 tarihli bir fermana göre, bir süreden beri bazı kimseler Tokat Voyvodalı̆̆ı'nın "umûrına müdâhale kaydında olduklarından" mukataa malının eksilmesine ve zarar görmesine sebep olmuşlardır. Bu durum üzerine Beyhan Sultan'ın kethüdası Ahmed Azmi Efendi, yazdığı bir takririyle müdahalenin önlenmesi için emr-i şerif yazılmasını talep etmiştir. Hazine-i Âmire'deki başmuhasebe defterlerinin incelenmesinden sonra, Tokat Voyvodalığı mukataasının "ma'lûmü'l-mikdâr mâl ve mu'accele ile sultân-ı mûmâ-ileyhânın iştirâken ber-vech-i mâlikâne uhdesinde oldığı" bu sebepten "bu makūle mâlikâne virilen mukāta'ât ve maktû'ât ve kurâ ve müzârĩ vüzerâ ve mîr-i mîrân ve mütesellimler ve sâ' ir ehl-i örf tâ'ifesi taraflarmdan dahl u ta'arruz olunmayup ederi olur ise men' $u$ def " olunması, ${ }^{120}$ ayrıca voyvodalı mukataası "mefrûzü'l-kalem ve maktû' 'ü'l-kıdem min külli' l-vücûh serbestiyet vechile hayatda olduklarında te' bîden ber-vech-i mâlikâne" berât-ı âlî-şân ile "mutasarnıf olmaları düstûrü'l-amel tutulan meşrût-ı mer'iyyeden idügi", gerektiğinde Tokat Voyvodalığı mukataası reayalarının "meclîs-i şer'e ihzârı ve hukūk-ı şer'iyye tahsîli ve lede'l-iktizâ ahz u habs ve lâzım gelen te'dîblerinin icrâsı voyvodaları ma'rifetiyle rü'yet" olunması hususunda daha önce Evâil-i Rebiyülâhır 1216/Ağustos ortaları 1801 senesinde fermanın yazıldığı kayıtlardan anlaşlmışur ${ }^{121}$. Hem Ahmed Azmi'nin takririne ve hem de bu fermana istinaden Tokat naibine 1808 tarihli hasseten bu ferman yazılıışur. Ferman şu ifadelerle sonuçlanır: "Sen ki nâ'ib-i mûmâ-ileyhsün bâlâda bast u beyân ve tasrîh $u$ ayân kılındığı üzre mukāta' $a-i$ mezbûrenin şirâze-i nizâm ve vâridâtı tatrîk-i halelden sıyânet ve re'âyâsı dahi mezâlim u ta'addiyatdan himâyet ve şurût-ı

119 Sivas Ser'iyye Sicili, 02 Zilhicce 1217/25 Mart 1803'ten naklen Necdet Sakaoğlu, Anadolu Derebeyi Ocaklarından Köse Paşa Hanedanı, İstanbul 1998, s. 155.

${ }^{120}$ TSS, $11,89$.

${ }^{121}$ Ayni ferman. 
serbestiyetlerine ke-mâ yenbağî ri' âyet-i lâzımeden idügi ma'lûmın oldukda voyvodalık-ı mezkûr mukaddemden berü ne vechile zabt u idâre olunagelmiş ise bundan böyle dahi ber-mûcib-i şurût serbestiyetde re' âyası mezâlim ve ta'addiyandan himâyet olnnarak yine voyvoda-i mezbûr tarafundan zabt $u$ idâre olınup voyvodalık umûrına taraf-ı âhardan müdâhale itdirülmemesine bezl-i makderet ve hilâf-1 şurût-1 serbestiyetde ve muğâyir-i kadîm hareket ile vâridât-1 mukāta' anın kesr u tedennîsine mûcib olur hâlâta tasaddî idenlerin vâki' olan ta'addîlerinin ma' rifet-i şer'le def' ü ref' ine ihtimâm u dikkat ve mütenebbih olmayanlarınun li-ecli' t-te' dîb isim ve şöhretleriyle keyfiyyetlerini Der-i Sa' âdetime i' lâma müsâra' at eylemenüz bâbında fermân-ı âlîşânum sâdır olmışdur" ${ }^{\prime 22}$.

Diğer taraftan Tokat Voyvodalı̆ğ mukataası dahilinde ikâmet eden "vedí atullah" olan reaya fukarasına zulmeden eşkıya ve hazelenin rencideleri ve uygunsuz hareketleri meydana geldiğinde "iktizâ iden te'dîbleri voyvodalarının ma' rûf olan tezkeresi ve hâkim-i beldenin mürâselesiyle icrâ" olunmaktaydı. Ancak bazen voyvodaların tezkeresi olmaksızın, yalnızca naip mürâselesiyle nizama aykırı olarak cezalandırma işlemine başvurulurdu. Meselâ, 04 Safer 1223/01 Nisan 1808 tarihli bir fermana göre, bir süredir Tokat ahalisinden bazıları birbirlerine olan düşmanlıklarından dolayı voyvodalarının haberi olmayarak suçsuz bazı kimseleri "yalnız hâkimü'şş̧er' mürâselesiyle ahz ve vaz'-1 kal'a etdirdüklerinden bu keyfiyyet voyvodalarının kesr u nüfûzuna bâdî ve Tokad gibi belde-i azîmenin ihtilâl-i nizâmını mü 'eddî" olmuştur. Ahmed Azmi Efendi, "eşkıyâ makūlesinden birisinün te'dîbi lâzım geldükde âdet-i kadîme-i belde üzre voyvodalarının tezkeresi olmadukca yalnız hâkim-i beldenin mürâselesiyle vaz'-1 kal'a itdirülmemek üzere" emr-i şerif verilmesini takririyle bildirmiştir. Bu takrire istinaden Tokat naibi, voyvodası ve kale dizdarına hitaben eşkıya ve yaramaz taifesinden olanların cezalandırılmak üzere kaleye gönderilmeleri gerektiğinde "voyvodalarının tezkeresi olmadukca yalnız mürâsele ile icrâ-yı te' díblerine mücâseret olunmayup kadîmi ve olageldigi vechile bu makūle umûrın tanzîm ve temşîti ve müktezâsının icrâsı voyvoda-i mûmâ-ileyh ile bi' l-ittifâk görülüp nizâm ve intizâmı muhâfazaya kemâl-i dikkat u ihtimâm" olunmasını emreden ferman yazılmışur ${ }^{123}$.

122 Ayn ferman.

${ }^{123} T S S, 11,90 / 1$. 
Öte taraftan "Tokat Voyvodalığı mukāta'ası kazâsı ve nevâhisi ahâlileri" Sivas valileri için "eyâlet-i Sivas' dan ta 'yîn olınan imdâd-ı hazariyyeden ve seferler vukû 'ında imdâd-ı seferiyyeden hisselerine isâbet" eden miktarı şartlar muvacehesinde vaktinde ödemekteydiler. Ancak yukarıda da bahsedildiği gibi, Sivas vali veya mütesellimleri çeşitli adlarla kanunlara aykırı ve fermanlara muhalif olarak, halktan fazla akçe talep etmekteydiler. Hatta bünyelerinde bulunan delil ve tüfekçilerden 20 ve 30 'şar kişiyi mübaşirler ile kaza ve nahiyelere göndererek, zahire bahâ, ikramiye, kaftan ve devriye baha vb. isteklerle rencide etmekteydiler. Bu durumdan "ahâli ve fukarâ-yı memleket muzdaribü' l-yâl ve perîşanü'l-hâl" olduğundan, mezalim ve baskıların önlenmesini hâvî emr-i şerif isteği mahallinden arzuhal ve ilâmlarla İstanbul'a bildirilmiştir ${ }^{124}$

Sorunun kendisine ulaşması üzerine Sultan II. Mahmud Beyhan Sultan'ı malikâne uhdesinde olan Tokat mukataasına bağlı ahali ve reayanın baskı ve sıkıntulardan emin, rahat olmaları ve bu hususlara vali ve hakimlerin dikkat etmeleri gerekliyken, reayaya baskı yapılmasına rıza gösteremeyeceğini ve kanunlara aykırı davranışlara girişenlere müsaade edilmeyeceğini belirtmiştir. Ayrıca mukataa ve bağlı yerlere müdahalelerin olmamasına yönelik III. Selim tarafindan da daha önce ferman yazıldığını belirten Sultan, ${ }^{125}$ "ahâlî vü fukarâya bir vechile zulm ve gadr vukû' 'na kat' a rizâ-yı aliyyem olmayup" diyerek, Tokat voyvodası ve naibine hitaben ahali ve fukaranın ödemesi mecburi vergi dışında herhangi bir taleple baskıya maruz kalmamalarnnı emreden ferman göndermiştir ${ }^{126}$.

Aym konuda 25 Safer 1230/06 Şubat 1815 tarihinde Sivas valisi İbrahim Paşa da bir buyruldu yazmışur. Paşa, Tokat naibi ve voyvodasına Beyhan Sultan'ın havâssından olan Tokat Voyvodalığı mukataası "ahâlîsine ve gerek ehli zimmet re 'âyâsına" baskı yapılmaması hususunda emirler olmasına rağmen, bunlara uyulmayarak aykırı hareketlerde bulunulduğunun mahallinden bildirildiğini haturlatarak, "merkūm ahâlî vü re' âyânun yedlerinde olan evâmir-i aliyyenin infâz ve icrâsına ale'd-devâm dikkat ve vedĩa olan fukarâ ve

${ }^{124} T S S, 12,72$,

125 Evâsıt-1 Cemâziyülevvel 1218/Ağustos sonları-Eylül başları 1803 tarihinde III. Selim dōneminde "mûcibince amel oluna" denilerek hatt-1 hümâyun ile "Sivas vâlileriçün senede iki taksit ile tertîb-i hazariyyeden Tokad ve nevâhisinûn sicilde makayyed hisse-i hazariyyelerini ve seferler vukût inda hisse-i seferiyyelerini vakt u zemâniyle mahallinde tamâmen edâ eyledükden sonra ziyâde akçe talebi ve mübâşiriyye ve zahîre-bahâ ve kaftan-bahâ ve devriyye nâmı ve sâ'ir bida' ve mezâlim ile ta' addî ve müsvedde ile bi-lâ mûcib ve bi-lâ-fermân külliyetlü mübâşir irsâli ile tecrîm itdirilmemesiçün" emr-i şerif verildiği bilgisi vardır. TŞS, 12, 72.

${ }^{126}$ Aym ferman. 
zu'afânın himâyet ü sıyâneti ile perîşânlı̆̆ı mûcib ve ihtilâl-i nizâm-ı mukāta ayı müstevcib-i halâtdan ittikā vü mübâ'adet" olunmasını emretmekteydi ${ }^{127}$.

1819 ylında da Tokat Voyvodalığı'na çeşitli müdahaleler devam etmiştir. Meselâ, 13 Şaban 1234/07 Haziran 1819 tarihli bir fermana göre, Beyhan Sultan'ın kethüdası Ahmed Azmi Efendi mukataa şartlarına aykırı olarak Tokat Voyvodalığı malına ve voyvodalarına bazı kimselerin baskılarının de'am ettiğini, bu durumun mukataa gelirlerinin azalmasına sebep olduğunu belirterek, müdahalelerin önlenmesi hususunda bir fermanın yazılmasını talep etmiştir. Hazine-i Âmire kayıtlarında yapılan inceleme sonrasında "voyvodalık-ı mezkûrun kâffe-i â'idât ve hâsılât ve serbestiyetini kadîmden olageldigi vechile zabt u rabuçün" fermanın ve ayrıca "Tokad ve nevâhisi ahâlîleri imdâd-ı hazariyyelerini vakt u zemâniyle te' diye eylediklerine binâ'en vâlî vü mütesellim taraflarından sâ'ir bahâne ile zulm ve ta'addî olunmamak üzere" 1225/1810 tarihinde bir fermanın yazıldığını Darbhâne-i Âmire nazırı Abdurrahman Sabit Efendi belirtmiştir. Bu bilgiler çerçevesinde voyvodaların serbest oldukları, vali ve mütesellim taraflarından baskı yapılmamasını hâvî bu ferman yazılmıştur ${ }^{128}$.

Tokat voyvodaları kuvvet ve iktidarların bir sebeple kaybettiklerinde, mukataa mallarına etraftan müdahaleler daha fazla söz konusu olmaktaydı. Böyle durumlarda hem bölgeden arzuhal ve mahzarlar hem de Sivas valisi tarafından tahriratlarla sorun İstanbul'a bildirilirdi. Örneğin, $15 \mathrm{Safer}$ 1240/09 Ekim 1824 tarihli bir fermana göre, Tokat voyvodası Salih Ağa'nın "umûr ve iktidân olmadığundan ... ahâliden ba'zı eşhâs makūlesinin re' yine münâsebeti hasebiyle" ahali nezdinde nüfüzunun kalmadı̆̆, azledilerek yerine muktedir birinin atanması hususu Sivas valisi Mehmed Paşa tarafindan İstanbul'a yazılmıştur. Ayrıca Mehmed Paşa kaimesinde, 200'den fazla kișinin Sivas'a gelip, hesaplarının görülmesi için İstanbul'a gideceklerini belirttiklerini, bunun kendisi tarafından engellendiğini, ellerine buyruldu ve yanlarına mübaşir verilerek kazalarına geri gönderildiklerini belirtmekteydi. Aynı konuda Tokat ahalisi de yazdıklan ilam ve mahzarında, kazadaki çarşı halkından İslam ve reaya 10 kişinin kazaya nefret salarak vilayet işlerini kendilerine

${ }^{127} T S S$, 19, 89/1. Aynı konuya istinaden Evâsıt-1 Safer 1225/Mart sonlanı 1810 ve Evâhir-i Rebiyülevvel 1233/Şubat başları 1818 tarihlerinde de Tokat mukataası kaza ve nahiyeleri ahalilerine Sivas valileri tarafından hazariyye ve seferiyye dışında bir bahane ile tekâlif talep edilmemesi konusunda ferman gōnderilmiştir. TSS, 22, 90.

${ }^{128} T S S, 24,36 / 3$. 
ihale ettirmek istediklerini, bu amaçlarına ulaşınak için bazı halkı tahrik ederek yedi senelik vilayet masrafinın muhasebesinin görülmesine yönelik isteklerde bulunduklarını, valinin de hesap işlerinin görülmesi için buyruldu ile mübaşir gönderdiğini, halbuki kaza masrafinın şehir kethüdası vasıtasıyla görüldüğünü, her salyane döneminde mahkemece hesabın görülerek masraf defteri hazırlandığını, bu sebepten masraf konusunda kimsenin "şekk ü şübhesi" olmadığını, ancak adı geçen 12 kişinin ${ }^{129}$ kazanın işlerine "müdâhale ile memleketi fesâda vermiş oldukları"nı belirterek "voyvodaları mûmâ-ileyh Sâlih zîde mecduhû ile kazâ-i mezbûr müftîsi el-Hâc Mehmed Efendi' den bi' l-cümle hoşnûd ve râzı olarak haklarmda bir gûne inhâ ve iştikâ' vukû' gelür ise havâle sem 'î ve i' tibâr buyırılmamasını" istirham etmişlerdir. Bu bilgiler muvacehesinde Mehmed Paşa'ya, iddiacıların ortaya koyduğu muhasebe maddesinin oldukça fazla olduğu, muhasebe konusunun ferman ile açığa çıkması gerektiği, kendi bilgileri ile halkın bildirdiklerinin kıyaslanarak sorunun Darbhâne tarafindan atanacak bir mübaşir ile yerinde doğru dürüst ahali ve reayaya sorularak araşturılması ve durumun İstanbul'a yazılması, ancak ondan sonra gerekenin yapılacağı bildirilmiştir ${ }^{130}$. Bu fermandan iki gün sonra, 17 Safer 1240/11 Ekim 1824 tarihinde bu defa Tokat kadısı ve bilcümle ileri gelenlere aynı konu ile ilgili Darbhâne-i Âmire tarafindan bir buyruldu yazılmışur. Buyrulduda konunun yerinde araştırılması için Ömer Vecdi'nin mübaşir atandığı, sorunun ahali ve reayadan sorularak doğruca tahkik edilmesi ve İstanbul'a yazılması istenmekteydi. Buyruldu şöyle sonuçlanmaktadır: "Voyvoda-i mûmâ-ileyhin hâl ü keyfiyyeti ve iddi'â olınan muhâsebe maddesinün keyfiyyetini cümle ma'rifetiyle ahâlî vü re'âyâdan garaz $u$ nefretden â'rî vechile tahkîk-birle keyfiyyetin Der-i sa' âdet'e arz ve iş 'ârna mezîd ihtimâm u dikkat eylemenüz içün Darbhâne-i Âmire'den işbu buyruldı tahrîr ve tesyîr olunmışdur" ${ }^{131}$. Daha sonra bu işlemin ne şekilde sonuçlandığına dair bir belge bulamadık.

\section{Voyvoda Yolsuzluklan ve Servetlerinin Kaynağı: Katuroğlu Üveys Bey Örneği}

Tokat Voyvodalığı mukataası malına değişik zamanlarda vali, mütesellim ve naip gibi devlet görevlilerinin yanında halk, eşkıya vb. taraflarından se-

\footnotetext{
${ }^{129}$ Metnin biraz yukarısında 10 kişiden sōz edilmektedir.

130 Sivas valisi Mehmed Paşa ve mübaşir Ömer Vecdi Efendi'ye hitaben gönderilen 15 Safer 1240/09 Ekim 1824 tarihli ferman. TŞS, 29, 75/2.

131 TSS, 29, 76/2.
} 
bepsiz yere müdahalelerin olduğu ve gereğinden fazla akçe talep edildiği yukarıda açıklanmıştı. Bunun yanında çoğu zaman Tokat mukataasını yöneten voyvodalar da yolsuzluk yapmakta, zimmetlerine fazla akçe geçirmekte ve ahaliye baskı uygulamaktaydılar. Yani voyvodalar, kanunlara aykırı olarak, kendi nam ve hesaplarına fazla vergi salmakta ve tevzî' defterlerine de akçe koydurmaktaydılar. Şer'iye sicillerindeki ferman ya da buyruldularda, voyvodalığa atanan kişiler, genellikle işin ehli, ahali ve reaya koruyucu olarak nitelendirilmelerine rağmen, çoğu zaman azledilmeleri de, yine halka yaptıkları yolsuzluk ve haksızlıklarla olmaktaydı. Meselâ, 1815-16 yıllarında iki sene Tokat Voyvodalığı kendisine ihale olunan Sivas valisi Osman Paşa, mukataayı Tokath Katuroğlu Üveys Bey'e iltizam etmiştir. Ancak bir müddet sonra işlerin ve ilişkilerin iyi gitmediği ve sorunların ortaya çıkuğı görülmüştür. Belgelere göre, hem ihalenin asıl sahibi Sivas valisi Osman Paşa, hem de voyvodası Üveys Bey mukataa dahilindeki gelirlerden fazlaca akçe almaya başlamışlardır. Bunların "gerek dâhil ve gerek hâric ez-defter" bir senede tahsil ettiği meblağın miktarı 1.275 kîseye (637.500 kuruş) ulaşmışur. Ayrıca Sivas valilerinin oturduklanı sarayın tamiri için ferman ile karara bağlanan $75.000 \mathrm{ku}$ ruşluk masraftan, Tokat kazası hissesine 5.005 kuruş ${ }^{132}$ isabet etmesine rağmen, Voyvoda Üveys Bey, kanunlara ve uygulamalara aykırı olarak 22.750 kuruş tahsil etmiştir. Tokat kazası ahalileri keyfi olarak akçe talebinin perişanlıklarına sebep olduğu, voyvodanın elde ettiği meblağın kendilerine iade edilmesi, görevden azledilip, Tokat'tan ihraç edilmesi ve başka bir voyvodanın tayin edilmesini İstanbul'a arzuhal, ilâm, mahzar ve defter takdim ederek bildirmişlerdir ${ }^{133}$.

Sorun, daha detaylı bilgi için Darbhâne-i Âmire nazırı Abdurrahman'a havale edilmiş ve bilgi istenmiştir. Nazır, hem bir dizi evraklanı tetkik ederek, hem de Tokat ahalilerini mahallinde sorguya çektirerek, Osman Paşa'nın deftere kayıtlı ya da defter dışı olarak ikramiye, faiz-i mukataa vb. adlarla 160.700 kuruş, voyvodası Üveys Bey'in de geri dönüşü olmayan 91.474 kuruş aldığı bilgisine ulaşmışur. Mukataanın çeyrek hissesi Beyhan Sultan'ın olduğundan, kethüdası Ahmed Azmi Efendi ile de muhabere de bulunulmuş, $O$ da, voyvodanın gereğinden fazla meblağ aldığının tespit edildiğini bildirmiştir. Ayrıca durum İstanbul'a gelmiş olan birkaç Tokathdan da soruşturulmuş,

${ }^{132}$ Bir belgede bu meblağ 5.500 kuruş olarak geçmektedir. Bk. TŞS, 22, 31/1. Biri sehven eksik ya da fazla yazılmıs olmalıdır.

${ }^{133}$ Tokat voyvodası Üveys Bey ile ahalinin muhasebelerini rü'yet içün gelen emr-i âli kaydı. TŞS, 22, 16/3; 17. 
onlar da voyvodanın mezalim ve baskısını beyan etmişlerdir. Diğer taraftan Sivas'taki saray tamiri için sonradan 110.250 kuruşa ulaşmış olan meblağın tahsili için emr-i şerif verilmiş olduğu, buna Sivas Eyaleti'nin toplam hazariyyesinden 15.000 kuruş kadar meblağın ayrılacağı, Tokat'ın hissesine ise aymı miktarda hazariyyenin isabet etmeyeceği, ancak 8.000 kuruş vermeleri lazım geleceği, saray tamiri masrafı namıyla da Osman Paşa'nın takriben üç yük 40.000 (340.000) kuruşa kadar akçe tahsil etmesi gerektiğini ifade eden nazır, bu konuda Tokat kazasına ne kadar hisse tevzî‘ olacağının belli olmadığı, ancak "zâlimiyye olarak ahâliden ol mikdâr mebâliğ alındığı vâki" midür degil midür" mahallinde "mevsûkü' l-kelîm" kimselerden araştırmaya ihtiyaç olduğunu ve mübaşir tayiniyle durumun mahallinden araşurılması gerektiğini, ancak ondan sonra etraflı bir karar verilebileceğini ilâm etmiştiir ${ }^{134}$.

Bu ilâma istinaden Evâsit-1 Receb 1232/Haziran ortalan 1817 tarihinde Tokat naibi, bu iş için görevlendirilen Dîvân-ı Hümâyun'dan eski sipahiler katibi mübaşir Mehmed Remzi, bilcümle ahali ve iş erlerine hitaben ferman yazılmıştur. Fermanın sonunda mübaşire ayrıca "zâlimiyye olarak ahâliden ol mikdâr mebâliğ alındığı vâki' midür degil midür serren ve alenen mevsûkü’kelîm kimesnelerden etrâfiyla su'âl ve tahkîk ve ma'rifet-i şer' ve cümle ma' rifetiyle rü' yet-i muhâsebe olınarak ba' dehû iktizâsına bakılmak içün keyfiyyeti şekk $u$ şübhe kalmayacak vechile ala vukû'ihî" İstanbul'a yazması ve "hâtur ve gönüle ri'âyetiyle vak'anın hilâfı kâl u kaleme alınmak câ'iz olmadiğı" haturlatulmışur ${ }^{135}$.

Yine 20 Rebiyülâhır 1232/09 Mart 1817 tarihinde aynı konuyla ilgili Sadrazam tarafindan da bir mektup yazılmıştur. Sadrazam, Tokat voyvodası Üveys Bey ile ahalinin hesaplarının görülmesi, voyvodanın "ehl-i İslâm ve re' âyânın ba'zısından karz süreti ve cürmiyye nâmıyla aldığı mebâliğden başka", mevcudu olmayarak "nefsiçün almış olduğu" 63.082 kuruşun ahaliye geri ödenmesi irade buyrulursa, voyvodanın Tokat'ta olan emlakının satılmasıyla bu paranın sahiplerine ödenmesi gerekeceğini belirtmiştir. Voyvodanın "her ne kadar kudreti der-kâr ise de terkîb olduğu tama' cihetiyle muhâlefet" ederse, buna bakılmamasını da isteyen sadrazam, halka yaptuğı mezalimden vazgeçmesi hususunda Üveys Bey'e, Cabbarzâde Süleyman tarafından da uyarılarda bulunulmasına rağmen, bunlara aldırmadığını

${ }_{135}^{134}$ Ayn ferman.

135 Ayni ferman. 
"kendüden emniyet-i ahâlî zâ'il olarak" voyvodalıktan azledilip, yerine bir başka voyvodanın atanmasını Tokat ahalisinin de istediğini bildirmiştir ${ }^{13}$.

Diğer taraftan voyvodanın usulsüzlüklerine meydan veren eski Sivas valisi Osman Paşa da aynı hukuksuz yollara tevessül etmiştir. İkramiye ve diğer adlar altında gereğinden fazla akçe almış, bazı suçsuz kişileri de "tecrîm ve tekdîr etmiş"tir. Tokat kalesi imamını da habsederek 7 (3.500 kuruş) kîse cürmiyye akçesi almıştır. Bu usulsüzlükleri sultana aktardığını da mektubunda belirten sadrazam, voyvodanın aldığı meblağın kendisinden alınması ve sahiplerine iade edilmesi, muhalefet ederse bütün emlak, akar ve hanesinin satularak akçenin iadesi, Osman Paşa'nın da imamdan cürmiyye adıyla meblağ almış ise, bunun da geri ödenmesi ve voyvodanın azledilerek, Kütahya'ya sürgüne gönderilmesi hususlarında emr-i şerifin irsal olunduğunu belirtmiş̦tir ${ }^{137}$.

Sadrazamın mektubuna istinaden Evâhir-i Ramazan 1232/Ağustos başları 1817'de Üveys Bey'in emval ve emlakinin satulması için Tokat naibi, mübaşir Mehmed Remzi, vücûh-ı ahâli ve bilcümle iş erlerine ferman yazılmışur. Fermanda Sivas valisi tarafından iki senedir Tokat Voyvodalığı iltizamen uhdesine verilmiş olan Katuroğlu Üveys Bey'in deftere kayıtı ve kayıtsız 1.275 kîse akçe tahsil ettiği, Sivas'taki sarayın tamiri için Tokat kazası hissesine 5.500 kuruş isabet etmesine rağmen, 22.750 kuruş almış olduğunun İstanbul'a iletildiği ve bu hususta mübaşir gönderildiği tekrar haturlatulmışur. Ayrıca voyvodanın ahalinin bazısından karz ve cürmiyye olarak aldığı meblağdan başka, kendi şahsı için aldığı 63.082 kuruşun da çoğunu ikrar ettiği, bu meblağın kendisinden alınması, muhalefetine bakılmaması, diğer taraftan imamdan meblağ alınmışsa geri ödenmesi, vermek istemezse emval, akar ve hanesinin satulması ve fazla alınan meblağın sahiplerine ödenmesi emredilmiştiri ${ }^{138}$.

Hem ferman hem de sadrazam mektubundaki bilgiler muvacehesinde araşurma yapan mübaşir Mehmed Remzi, Üveys Bey ile Tokat ahalisi arasındaki münasebetler ve alacak-verecek sorunları ile ilgili İstanbul'a yazdığı bir dizi yazıda, voyvodanın zulüm ve baskı yapuğını bildirmiş, voyvodalıktan azledilerek yerine başka birinin voyvoda atanmasını inha etmiştir. Ayrıca

136 Üveys Bey ve Osman Paşa konularında sadrazam tarafından bazı mevadda dair gelen mektup kayd. T\$S, 22, 29/3.

${ }_{137}^{137}$ Ayn mektup.

$138 T S S, 22,31 / 1$. 
Darbhâne-i Âmire nazırı Abdurrahman Bey de, 1232/1817 senesine mahsuben Tokat Voyvodalığı mukataasının eski Sivas valisi Osman Paşa'ya ihale edildiğini, ancak Paşa'nın Sivas Eyaleti valiliğinden azl ve idam edilerek, bütün muhallefatının devletçe zapt edilmiş olduğundan voyvodalık umurunun da boş kaldığını belirtmiştir ${ }^{139}$. Voyvodalığın 1232/1817 senesine mahsuben geri kalan aylardaki yönetimini "ber-vech-i emânet" sağlamak ve 1233/1818 senesinde de "bir kavî sarrâf ta'ahhüdüyle sâbıkı üzere iltizâmen ana der'uhde olmak şartıyla tanzîmi münâsib mülâhâza olınarak șart-1 mezkûr üzere" Tokat Voyvodalı̆̆ için bir voyvoda atanmasının zorunlu hale geldiğini belirten nazır, voyvodalık için birkaç aday ismi ilâmı ile bildirmiştir. Bu adaylardan Selanik Tütün Gümrüğü eski Emini Derviş Ali'nin geçmişte "ba'zı hayrî iltizâmlarda bulunmış rızâlarınca idâre etmiş mu'tedil âdem olduğunu" $\mathrm{n}^{140}$ tarafına bildirildiğini de belirten nazır, isimlerini verdiği kimselerden hangisi voyvoda atanırsa, voyvodalığın 1232/1817 senesi bakiyesini emaneten, 1233/1818 senesini de eski usûllerde iltizamen verilmesini belirtmiştir. Bu ilâma istinaden Tokat Voyvodalığı mukataasının iltizamı 19 Zilkade 1232/30 Eylül 1817 tarihli bir fermanla Derviş Ali'ye verilmiştir ${ }^{141}$.

Tokat Voyvodalığı mukataasını uhdesine alan Voyvoda Derviş Ali, aynı zamanda Osman Paşa'nın borçlarını ödeme yükümlülüğünü de üstlenmiştir. Meselâ, 14 Rebiyülâhır 1233/21 Şubat 1818 tarihli bir fermana göre, sarraflardan Hüdavirdioğlu Nazâret zımmi Dîvân-1 Hümâyun'a bir dilekçe sunmuş ve eski Sivas valisi Osman Paşa'nın zimmetinde olan 2 yük 98.896 kuruş (298.896 kuruş) alacağının kendisine ödenmesini talep etmiştir. Dilekçe muvacehesinde alacağın, Osman Paşa'nın Sivas'ta olan bakaya ve Tokat Voyvodalığı hasılatından tahsil edilmesi ve sarrafa ödenmesi konusunda daha önce bir ferman yazılmışur. Ayrıca kayıtlardan da 1232/21817 senesi sonuna değin voyvodalık hasılatını Voyvoda Derviş Ali toplayacağından, voyvodalığın sene sonuna kadar hasılat, Tokat'ta olan bütün zimemat ve bakayasının tahsili babında voyvodaya emr-i şerif yazıldığı, voyvodalığın "hâsılâtı her neye baliğ olur ise sarrâf-ı mersûm tarafindan kabzına me'mûra teslîm ve yedinden makbûz senedi ahz" olunması istenmiş ve ayrıca "mersûmın küsûr kalan

${ }^{139}$ Ramazan 1232/Temmuz-Ağustos 1817 tarihli voyvodanın nefyî hükmü. BOA, Cevdet Dahiliye, No. 4169.

140 Darbhâne-i Ȧmire nazırı Abdurrahınan, bu ifadesiyle voyvoda adayları arasından Derviş Ali'yi seçtiğini de göstermiş oluyordu.

${ }^{141} T S S S, 22,52$. Ayrıca Tokat Voyvodalığı mukataasının 114 günlük tahsilat, mesarifat vb. sürecini gösteren 11 Cemaziyülevvel 1233/19 Mart 1818 tarihli müfredat defterinden mukataaya hangi gelir kalemlerinin bağlı olduğunu öğrenmekteyiz. TŞS, 22, 94/1. 
matlûbunun Sivas tarafinda olan bakâya ve zimemâtundan tahsîli bâbında" Sivas valisi Ali Paşa'ya da emirler verildiği anlaşılmıștur. Şimdi hasseten verilen bu ferman, yukarıdaki açıklamaları kapsayacak şekilde Derviş Ali'ye hitaben aşağıdaki emirlerle sona ermektedir: "Voyvodalık-ı mezkûrın senesi hitâmına değin hâsılâtu her neye baliğ olur ise Tokad'da olan zimemâtuyla ma' ân ma'rifet-i şer' ve ma' rifetinle mersûm tarafindan kabzına me'mûra teslîm ve yedinden makbûz senedi ahz-birle mukaddem sudûr iden emr-i şerîfim mûcibince mukāta' a-i mezbûrnn sene-i mezkûre ibtidâsından Şubatu gâyetine degin hâsılâtı her ne ise hisâbı rü'yet olınmak üzere memhûr ve mümzâ defterinin der-i Sa âdetime irsâli hususına mübâderet eyleyesün"142.

Bu fermana istinaden Tokat voyvodası, İstanbul'da Han-1 Cedid'de oturan Hüdavirdioğlu Hoca Nazâret tarafına Osman Paşa bakayasından 20.000 kuruş, yine saray tamiri akçesinden de 22.754 kuruş olmak üzere "Tokad ve nevâhisü kazâsı ahâlileründen" toplam 42.754 kuruş toplayarak göndermiş, ahaliye de "vakt-i hacette ibrâz" etmek üzere senet vermiştir ${ }^{143}$.

\section{Sonuç}

Tokat Voyvodalığı ve tevâbi' mukataası, III. Selim ve II. Mahmud dönemlerinde Darbhâne-i Âmire tarafından yönetilmekte ve ihaleye verilmekteydi. Aynı dönemde mukataada Sultan III. Selim'in kız kardeşi Beyhan Sultan'ın da hisseleri bulunmaktaydı. Beyhan Sultan'm mukataada olan rub' hissesi ber-vech-i malikâne olarak ölümüne kadar devam etmiştir. Ölümü ile birlikte hisse, Ceyb-i Hümâyun hazinesine devredilmiştir. 1830'dan sonra voyvodalık mukataası, Mukataât Hazinesi'ne bağlanmıştır. Tanzimat'la birlikte voyvodalık birimi yeni düzenlemelerle birlikte muhassıllığa dönüștürülmüştür.

Yıllık olarak iltizama verilen mukataayı yönetmek üzere bir voyvoda tayin olunurdu. Voyvoda, sancakbeyi yetkisine haiz idi. Malî işlerle birlikte askerî,

${ }^{142} T S S, 22,96$.

143 TŞS, 23, 36/2. Tokat voyvodası Derviş Ali'nin emr-i âlî ile görevlendirilmesini hâvî halasname kaydı. Belgenin üstünde rakamla toplam 42.754 kuruş toplandığı yazılmasına rağmen, metinde "ikrâmiyye nâmıyla yigirmiikibin guruş" alındığı kaydı vardır ki, bu durumda toplam 44.754 kuruşluk bir meblağ ortaya çıkar. Ancak yine aymı işe memur edilen dergah-ı âlî gediklülerinden Hacı Mehmed'in düzenlediği başka bir halasnâmede Tokat ahalilerinden "ceste ceste" 42.754 kuruş alındığı kaydı vardır. TŞS, 23, 44/1. O halde 42.754 kuruş toplandığı bilgisi doğru olanıdır. 
idarî vb. yükümlülükleri de vardı. Voyvodalık mukataası ilk elden iltizama verildiği gibi, ihaleyi alan Sivas valileri vb. memurlar da bir başkasına iltizama verebilmekteydi.

Mukataa serbestiyet üzere yönetildiğinden, voyvoda dışındaki ehl-i örf mensupları müdahalede bulunamazlardı. Kanunlarla tespit edilmiş vergiler dışında keyfi olarak hiçbir talepte bulunulamazdı. Mukataa, ylın Martından itibaren takip eden yılın Şubauna değin, yani bir malî yll için iltizama verilmekteydi. Gerekli görüldügünde iltizam süresi uzatulabilirdi. İltizam sahibi, gerekli ödemeleri yapacağına dair Darbhâne-i Âmire'ye sarraf kefaletiyle bir deyn temessükü vermekteydi. İltizam sözleşmesinin bitiminde de devir-teslim işlemi gerçekleştirilir ve hesap kapatılırdı.

İncelediğimiz dönemde Tokat Voyvodalığı mukataasına gerek Sivas valileri ve gerekse halktan bazı kimselerin müdahalesi eksik olmamıștur. Bazen voyvodalar da halktan gereğinden fazla vergi talep etmiş ve yolsuzluk yapmışlardır. Mukataa malına zarar gelmemesi, uygunsuz hareketlerden kaçını-ması hususlarında İstanbul'dan devamlı surette bölgeye fermanlar gönderilmesine rağmen, sorunlar devam etmiştir. 


\section{KAYNAKLAR}

\section{Arşiv Kaynaklan}

1. Milli Kütüphane, Yazmalar Bölümü, Tokat Şer'iye Sicilleri

Defter No. 01, 02, 03, 04, 05, 06, 07, 09, 11, 12, 13, 14, 15, 16, 17, 18, 19, $20,21,22,23,24,26,27,28,29,30,31,32,34,35,36,37,38,39,40,45,47$, $49,51,52,54$ (42 adet defter).

\section{Başbakanllk Osmanlı Arşivi Tasnifleri (BOA)}

1. Hatt-1 Hümâyun No.: 20324; 20324 A; 20324 B; 20324 C.

2. Cevdet Maliye, No.: 6093; 9279; 21332, 22201; 26605 L.

3. Cevdet Dahiliye, No.: 4169.

\section{Kitap ve Makaleler}

AÇIKEL, Ali; Changes in Settlement Patterns, Population and Society in North Central Anatolia: A Case Study of the District (kaza) of Tokat (1574-1643), Basılmamış Doktora Tezi, Manchester Üniversitesi 1999.

CEZAR, Yavuz; Osmanlı Maliyesinde Bunalım ve Değişim Dönemi (XVIII. Yüzyldan Tanzimat'a Mali Tarih), Alan Yayıncılık, İstanbul 1986.

CINNLIOĞLU, Halis Turgut; Osmanlılar Zamanında Tokat, II. ve III. Kısım, Tokat Matbaası, Tokat 1950-1951.

ÇİAKÇA, Murat; İslam Dünyasında ve Batı'da İş Ortaklan Tarihi, Tarih Vakfi Yurt Yayınları, İstanbul 1999.

CADIRCI, Musa; Tanzimat Döneminde Anadolu Kentlerinin Sosyal ve Ekonomik Yapıları, TTK Basımevi, Ankara 1991.

GENÇ, Mehmet; "Osmanlı Maliyesinde Mâlikâne Sistemi”, Osmanlı İmparatorluğunda Devlet ve Ekonomi, 2. Baskı, Ötüken Yayınevi, İstanbul 2002.

GÖKBILGIN, Tayyib; “Tokat”, İslam Ansiklopedisi, 2. Baskı, MEB Basımevi, İstanbul 1979.

KHOURY, Dina Ruzk; Osmanl İmparatorluğu'nda Devlet ve Taşra Toplumu, Musul, 1540-1834, (Çev.: Ülkün Tansel), Tarih Vakfı Yurt Yayınları, İstanbul 1999.

SAKAOĞLU, Necdet; Anadolu Derebeyi Ocaklarından Köse Paşa Hanedanı, 2. Baskı, Tarih Vakfi Yurt Yayınları, İstanbul 1998. 
ÖZKAYA, Yücel; Osmanlı İmparatorluğunda Âyânlık, TTK Basımevı, Ankara 1994.

ÖZVAR, Erol; XVII. Yüzyılda Osmanlı Taşra Maliyesinde Değişim: Rum Hazine Defterdarlığından Tokat Voyvodalı̆̆ına Geçiş, Marmara Üniversitesi Sosyal Bilimler Enstitüsü Basılmamı̧ Doktora Tezi, İstanbul 1998.

; "XVII. Yüzyılda Osmanlı Taşra Maliyesinde Değişim: Rum Eyaletinde Hazine Defterdarlığından Tokat Voyvodalığına Geçiş", XIII. Türk Tarih Kongresi, Ankara, 4-8 Ekim 1999, Kongreye Sunulan Bildiriler, III. Cilt, III. Kısım, TTK Basımevi, Ankara 2002. ; Osmanlı Maliyesinde Malikâne Uygulaması, Kitabevi, İstanbul 2003.

ŞiMșiRGIL, Ahmet; "Osmanlı Taşra Teşkilatunda Rum Beylerbeyliği”, Türklük Araşturmaları Dergisi, Sayı 5, İstanbul 1989.

; Osmanlı Taşra Teşkilâtunda Tokat (1455 - 1574), Marmara Üniversitesi Sosyal Bilimler Enstitüsü Basılmamış Doktora Tezi, İstanbul 1990.

TABAKOĞLU, Ahmet; Gerileme Dönemine Girerken Osmanlı Maliyesi, Dergah Yayınları, İstanbul 1985.

ULUÇAY, M. Çağatay; Padişahların Kadınları ve Kızları, TTK Basımevi, 2. Basku, Ankara 1985.

YLMAZÇELIK, İbrahim; XIX. Yüzyılın İlk Yarısında Diyarbakır (1790-1840), TTK Basımevi, Ankara 1995. 


\title{
EKLER
}

\section{Belge: 1}

\author{
Tokat Şer'iyye Sicili, Defter No. 11, Sayfa No: 90, Belge No: 1
}

\section{Voyvodalann Nüfuzlanna Halel Gelmemesi ve Ahaliye Zulmedilmemesini Hâvî Fermân-ı Hümâyûn}

Kıdvetü'n-nüvvâbi'l-müteşerri'în Tokat nâ'ibi mevlânâ zîde ilmuhû ve kıdvetü'l-emâcid ve'l-a'yân Tokat voyvodası Metin Mehmed zîde mecduhû ve kıdvetü's-sıkati'l-müstahfizîn Tokat dizdârı zîde hıfzuhû tevkï'-i refi'-i hümâyûn vâsıl olıcak ma'lûm ola ki,

Seyyidetü'l-muhaddemât ekliletü'l-muhassenât tâcü'l-mestûrât zâtü'l-alî ve's-sa'dât emmizâdem Beyhân Sultan dâmet ismetühâ ve zîdet iffetûhanın ber-vech-i mâlikâne uhdesinde olan Tokad Voyvodalığı mukāta'ası külliyetlü mâl ile mukayyed vâridât-1 cesîme-i mîrîyyemden olup öteden berü mefrûzü'l-kalem ve maktû'ü'l-kıdem min külli'l-vücûh serbestiyyet üzre zabt u tasarruf olınarak vedî'atullâh olan re'âyâsının mezâlim ve ta'addiyâtdan vikâyesi ve voyvodalarına mufavvaz ve eşkıyâ ve hazele makūlelerinin re'âya fukarâsına tasallut ve rencîdeleri ve ba'zı nâ-hemvâre hareketleri zuhûrında iktizâ iden te'dîbleri voyvodalarının ma'rûf olan tezkeresi ve hâkim-i beldenin mürâselesiyle icrâ olınmak iktizâ ider iken bir müddetden berü bu kâ'ideye ri'âyet olunmadığından ahâliden ba'zıları birbirlerine olan nefsâniyyetlerini icrâ zımnında voyvodalarının ma'lûmı olmayarak bi-lâ-cürm ba'zı kimesneleri yalnız hâkim-i şer' mürâselesiyle ahz ve vaz'-1 kal'a itdirdüklerinden bu keyfiyyet voyvodalarının kesr-i nüfûzuna bâdî ve Tokad gibi belde-i azîmenin ihtilâl-i nizâmını mü'eddî olduğımı beyân-birle ba'd-ez-în belde-i merkūmeyi ihtilâlden sıyânete voyvodaların nüfûzını kesr ve ibdâlden vikâye eşkıyâ makūlesinden birisinün te'dîbi lâzım geldükde âdet-i kadîme-i belde üzre voyvodalarının tezkeresi olmadukca yalnız hâkim-i beldenin mürâselesiyle

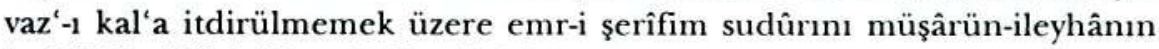
kethüdâsı iftihârü'l-emâcid ve'l-ekârim Ahmed Azmi dâme mecduhû bâ-takrîr inhâ itmekden nâşî mûcibince amel ve hareket olınmak fermânım olmağın hasseten işbu emr-i şerîfim ısdar ve ile irsâl olunmışdur. İmdi vusûlünde sen ki nâ'ib-i mûmâ-ileyhsün bâlâda bast-1 beyân olduğu üzre mukāta'a-i mezbûre mukāta'a-i cesîme-i mîrîyyemden olup ez-kadîm serbestiyyet üzre 
voyvodalar tarafindan zabt $u$ rabt olunagelmekle bundan böyle dahi kâ'ide-i kadîme ve âdet-i beldeye ri'âyet ve mûcib-i ihtilâl-i nizâm olur harekât-1 nâbe-câdan hazer u mücânebet ve asâyiş-i emn ü rahat-ı fukarâ esbâbını istihsâle sarf-ı makderet olınmak müktezâsı irâde-i aliyyemden oldıgı ma'lûmın oldukda fî-mâ-ba'd o makūle eşkıyâ ve hazelenin iktizâ iden te'dîbleri ve kal'aya vaz'ı lâzım geldükde voyvodalarınun tezkeresi olmadukca yalnız mürâsele ile icrâ-yı te'dîblerine mücâseret olınmayup kadîmi ve ola geldigi vechile bu makūle umûrın tanzîm ve temșîti ve müktezâsının icrâsı voyvoda-i mûmâ-ileyh ile bi'l-ittifâk görülüp nizâm ve intizâm-ı muhâfazaya kemâl-i dikkat ve ihtimâm eyleyesün ve sen ki voyvoda-i mûmâ-ileyhsün sen dahi bu misillü umûrı ma'rifet-i şer'le oldığı vechile rü'yet garez ü nefsaniyyet ve edeblerine zehâb ile hilâf-1 rizâ-yı şâhânemden müretteb hâlet ve hareketi tecvîzden tevakkî vü mübâ'adet ve sen ki dizdâr-ı merkūmsın sen dahi mûcib-i emr-i şerîfimle amel ü hareket eylemenüz bâbında fermân-ı âlî-şânım sâdır olmışdur. Buyurdum ki hükm-i şerîfimle vardukda bu bâbda vech-i meşrûh üzre şeref-yâfte-i sudûr olan işbu emr-i şerîf-i celilü'ş-şân-ı vâcibü'l-ittibâ' ve lâzımü'l-imtisâlimin mazmûn-1 münîfi-birle âmil olasız. Şöyle bilesüz alâmet-i şerîfe i'timâd kılasız. Tahrîren el-yevmi'r-râbi' Safer li-sene selase işrîn ve mi'eteyn ve elf.

Konstantiniyye-i mahrûse

\section{Belge: 2}

Tokat Ser'iyye Sicili: $12,47 / 1$

\section{Voyvodalık Sartnâmesini İhtiva Eden Zabıtnâme}

Voyvodalık şartnâmesi

Bâ'is-i tahrîr-i hurûf budur ki,

Serbestiyyet üzere mâlikâne uhdemizde olan Tokad mukāta'asını işbu bin ikiyüz yigirmidört senesi Mart ibtidâsından sene-i merkūme Şubatı gâyetine varınca bir sene kâmile zabt ve iktizâ iden mâl-ı mîrî ve kalemiyyesiyle mahallinde virilecek vezâyifi vakt u zemâniyle edâ ve senedâtunı tarafimuza teslîm eylemek şartuyla dârende-i temessük şilahşörân-ı hazret-i cihândârînden Mehmed Behlül Bey'e iltizâm ve tefvîz olunmağla imdi mukāta'a-i mezbûre sene-i merkūmeye mahsûben mûmâ-ileyh tarafindan zabt u rabt ve icâb iden a'şâr-1 şer'iyye ve rüsûmât ve tevcîhât-1 sâ'iresi kadîmden olageldigi üzre 
ahz u kabz olınup tarafimuzdan ve taraf-1 âhardan müdahâle ve mühâlefet olunmaması içün işbu zabıt-nâme ketb ve i'tâ olundı.

Beyhân Sultân hissehâ-i mukāta'a-i mezbûr

\section{Belge: 3}

Tokat Ser'iyye Sicili: 12, 72

Ahaliye İyi Davranılması ve Zulüm Yapılmaması

\section{Konusunda Ferman-1 Hümâyun}

Kıdvetü'n-nüvvâbi'l-müteşerri'în Tokad kazâsı nâibi mevlânâ zîde ilmuhû ve kıdvetü'l-emâcid ve'l-a'yân Tokad voyvodası zîde mecduhû tevkī'-i refi'-i hümâyûn vâsıl olıcak ma'lûm ola ki,

Taht-1 âlî-baht-1 Osmânî üzre cülûs-1 hümâyûn-1 sa'âdet-makrûnım vâki` olup umûmen tecdîd-i ahkâm-ı fermânım olmağın seyyidetü'l-muhaddemât ekliletü'l-muhassenât tâcü'l-mesturât Beyhan Sultan dâmet ismetühâ ve zîdet iffetühânın ber-vech-i mâlikâne uhdesinde olan Tokad mukāta'ası kazâsı ve nevâhisi ahâlileri üzerlerine edâsı lâzım gelen Sivâs vâlîleriçün eyâlet-i Sivas'dan ta'yîn olınan imdâd-ı hazariyyeden ve seferler vukû'inda imdâd-ı seferiyyeden hisselerine isâbet ideni şurûtu üzre vakt u zemâniyle mahalline edâda kusûrları olmayup vâlî ve mütesellimler taraflarından ikrâmiyye ve kaftân ve devriyye bahâ nâmı ve sâ'ir bida' ve mezâlim ve ta'addiyât ile bir vechle rencîde olınmaları icâb itmez iken bir müddetden berü Sivas vâlîleri ve mütesellimler taraflarından ziyâde akçe talebi ve hilâf-ı rızâ ve muğâyir-i emr-i âlî zahîre bahâ ve ikrâmiyye ve kaftan bahâ ve sâir bida' ve mezâlim ile ta'addî olduklarından mâ'adâ bi-lâ-mûcib-i müsvedde ile tüfenkçi ve delîl tâ'ifelerinden yirmişer ve otuzar nefer ile mübâşirler vurûd ve bayrak akçesi ve nâm-ı diğer ile fukarâyı darb iderek hilâf-ı şer' ve bi-lâ murâfa'a cebren mebâliğ-i kesîre ahz eyledüklerinden ahâli ve fukarâ-yı memleket muzdaribü'lyâl ve perîșânü'l-hâl olduklarından bahisle vâki olan mezâlim ve ta'addiyânın men' ü def'i bâbında emr-i şerîfim sudûrı mukaddemâ bâ-i'lâm ve tahrîrât inhâ olunmıs mukāta'a-i merkūme-i müşâuñn-ileyhânın mâlikâne uhdesinde olup ahâli ve re'âyâsının vücûh-ı mezâlimden vikâyeleriyle âsûdnîşîn müzelle-i emn ve rahat olmalarına vülât ve hükkâm taraflarından kemâl-i ihtimâm ü dikkat olınmak lâzımeden iken ol vechile ta'addîye ibtidâr olunması bi'l-vücûh rızâ-yı hümâyûnımın muğâyiri olup fi-mâ-ba'd külliyen 
def' ve murâd ve merâsim-i i'tiyâd-1 mülûkânem olmakdan nâşî müktezâ-yı dîvân-1 hümâyûnımdan lede's-su'âl Sivas vâlîleriçün senede iki taksît ile tertîb-i hazariyyeden Tokad ve nevâhîsinün sicilde mukayyed hisse-i hazariyyelerini ve seferler vukû inda hisse-i seferiyyelerini vakt u zemâniyle mahalline tamâmen edâ eyledüklerinden sonra ziyâde akçe talebi ve mübâşiriyye ve zahîre bahâ ve kaftân bahâ ve devriyye nâmı ve sâ'ir bida' ve mezâlim ile ta'addî ve müsvedde ile bi-lâ-mûcib ve bi-lâ-fermân külliyetlü mübâşir irsâli ile tecrîm itdirülmemek içün emr-i şerîfim i'tâsı iktizâ eyledigi tahrîr olınmağla vech-i meşrûh üzre amel ve nizâm-ı kavîye rabita ile hilâfindan mübâ'adet olınmak bâbında ikiyüz onsekiz senesi Evâsit-1 Cemâziye'l-evvelinde hüdâvendigâr-1 esbâk merhûm ve mağfûrun-leh Sultan Selîm Hân tâb-1 serâhu zamanında mûcibince amel oluna deyü bâlâsı hatt-1 hümâyûn-1 şevket-makrûn ile müzeyyen virilen emr-i şerîfi ibrâz ve tecdîdi niyâz olunmağla vech-i meşrûh üzre amel olınmak fermânım olmağın imdi zamân-ı sâ'ir-i iktirân-1 şâhânemde ahâli vü fukarâya bir vechle zulm ü gadr vukû'ına kat'a rızâ-yı aliyyem olmayup vücûh-1 mezâlim ve ta'addiyâtdan vikâyetleriyle refâh ve râhatları matlûb-1 şâhânem idügi ve ba'de'l-yevm muğâyir-i emr u rızâ hareketine mütecâsir olanlar mazhar-atâb olacakları ma' lûmınuz oldukda bervech-i muharrer Sivas vâlîleriçün iki taksît ile müretteb hazariyyeden Tokad ve nevâhisinün sicilde mukayyed hazariyyelerini ve seferler vukû'inda dahi hisse-i seferiyyelerini şurûtı mûcibince tamâmen vakt u zemâniyle mahalline edâ eyledüklerinden sonra ziyâde talebi ve mübâşiriyye ve zahîre bahâ ve kaftân bahâ ve devriyye nâmı ve sâ'ir bida' ve mezâlim ile ta'addî ve müsvedde ile bi-lâ-mûcib külliyetlü mübâşir irsâliyle tecrîm olunmamaları husûsının ma'rifetinüz ile geregi gibi nizâma râbıta ve hilâf-ı hareket vukû'a gelmemek içün sicile kayd ile ale'd-devâm icrâsına ihtimâm u dikkat ve hilâf-ı fermân ve münâfi-i rızâ ve men'-i tecvîzden tevakkî ve mübâ'adet olınmak bâbında fermân-ı âlî-şânım sâdır olmışdur. Buyurdum ki vusûl buldukda bu bâbda vech-i meşrûh üzre şeref-yâfte-i sudûr olan fermân-ı vâcibü'l-ittibâ' ve lâzımü'l-imtisâlimin mazmûn-ı itâ'at-makrûnıyla amel ü hareket ve hilâfından hazer ü mücânebet eyleyesüz. Şöyle bilesüz alâmet-i şerîfe i'timâd kılasız. Tahrîren fî Evâhir-i Rebî'i'l-evvel sene erba'a ve işrîn ve mi'eteyn ve elf.

Konstantiniyyeti'l-Mahrûse 


\section{Belge: 4}

\section{Tokat Ser'iyye Sicili: 17, 29/1}

\section{Sivas valisi İbrahim Paşa'nun buyruldusu}

Şerî'at-şi âr Tokat kadısı fazîletlü efendi zîde fazluhû ve mefâhirü'l-emâsil ve'l-akrân a'yân ve zâbitân ve iş erleri zîde kadruhum inhâ olunur ki,

Bâ-hatt-1 hümâyûn-1 şevket-makrûn Darbhâne-i Âmirem tarafindan zabt u idâre olınan mukāta'ât-ı mîrîyyeden Tokat Voyvodalığı ve tevâbi'i mukāta'asının gerek Darbhâne-i Âmirem hissesi ve gerek devletlü ismetlü Beyhân Sultân aliyyetü'şş̧ân hazretlerinin uhde-i aliyyelerinde olan hissesi binikiyüz yigirmisekiz senesine mahsûben tarafimuza ihâle ile ve tarafımuzdan dahi bi'l-intihâb voyvoda nasb olunması irâde-i seniyye müktezâsından olmakdan nâşî sene-i mezkûre Maru ibtidâsından Şubatu gâyetine varınca bir sene-i kâmile zabt u rabt eylemek üzere Erzurumlu Hacı Yusufzâde Yusuf Ağa tarafımızdan bi'l-intihâb Tokat voyvodası nasb u ta'yîn ile sene-i merkūma mahsûben mukāta'a-i mezbûrın mûmâ-ileyhin zabt $u$ rabt ve vâki ${ }^{\circ}$ olan rüsûmât ve mahsûlatun kanûn-ı kadîm ve olageldigi üzre $a h z$ u kabz ve himâyet ve re'âyâya taraf-ı âhardan müdâhale ve ta'arruz olınmamak bâbında emr-i âli dahi sâdır olmağla imdi siz ki efendi-i mûmâ-ileyh ve muhâtabûn-1 sâ'irsüz mukāta'a-i mezbûr öteden berü zabt $u$ rabt ve kabz ve ne vechile rüsûmât ve mahsûlâtun kanûn-ı kadîm ve olageldigi üzre ahz u kabz ve himâyet-i re'âyâ ol vechile mûmâ-ileyhin dahi zabt u rabuna mu'âvenet hilâf-1 nzâ ve muğâyir-i emr-i âlî-şân ve ahâli-i fukârâ-yı ra'iyyete zulm u ta'addî gelmemesine dikkat eylemek içün tarafimuzdan dahi işbu buyruldu tahrîr ve ile irsâl olunmışdur. Bi-mennihî te'âlẩ vusûlünde mazmûn emr-i âlî ve mûcib buyruldı ile amel ve hareket ve hilâfindan tehâşi vü mücânebet eyleyesüz deyü.

23 Safer 1228. 


\section{Belge: 5}

\section{Tokat Ser'iyye Sicili: $18,79 / 1$}

\section{Voyvoda Atama ve Azledilme Buyruldusu}

Şerî'at-me'âb Tokat nâ'ibi zîde fazluhû ve me'zûn-ı bi'l-iftâ fekahatlû efendi zîde takvâhu ve kıdvetü'l-emâsil ve'l-akrân Mehmed Ağa zîde kadruhû ve fahrü'ss-şeref nakîbü'l-eşrâf vekîli ve serdârı ağalar ve sâ'ir iş erleri ve erbâb-1 sühân zîdet mukâdirehum inhâ olunur ki,

Eyâlet-i Sivas dahilinde beldeniz voyvodası hassa silahşörânından Yusuf Ağa'nın azl olınub yerine bir ra'iyyet-perver munsif ve mu'tedil ve kâr âşinâ voyvoda nasb ve ta'yîn olınmasını tarafımuza akdemce niyâz ü iltimâs ve recâ olunmış olmak hasebiyle bu def a dâiremiz müntehâbâtundan ve emekdâr-1 kadîmimizden bâlâda merkūmü'l-ism Gürcüzâde Silahdârım Mehmed Ağa' nın merkūma voyvoda nasb u ta'yîn ve irsâl olunmışdur. Gerekdir ki kâffe-i voyvodalığa dâ'ir umûr ve husûsında dirîne-i kadîm ve gayret-i müstedîm üzre mûmâ-ileyh tarafina inkıyâd ve müteyabi'at ve ibrâz-1 nakdiye-i gayret eylemelerinüz matlûb idügi ve sen ki voyvoda-i mûmâ-ileyhsin sen dahi müktezâ-yı isti'dâd-1 zâtun üzere âsâyiş-i hâl-i fukarâ ve ârâmiş-i bâl-ı zu'afâ te'dîb ve gûşmâl-i erâzil ve eşkyyâ ve emanetullâh-ı sukkân-ı memleketi pester-i râhatda ganûde-i âsâyiş itdürmemek ve cânîb-i hazret-i şehinşâhî ve tarafimuz içün isticlâb-1 da'vât-1 hayriyye zeylinde teşmîl-i şân ve gayret ve sarfen mâhasal ve sa'y ü miknet ve ibrâz-1 nakdîne-i liyâkat olınmak matlûb idügini hâvî dîvân-ı Sivas ve meștâ-yı Malatya'dan işbu buyuruldı tahrîr ü ısdâr ve voyvodai mûmâ-ileyhe i'tâen irsâl ve tisyâr olunmışdur. İnşâ'a'llâhû te'âlâ vusûlünde gerekdür ki bâlâda bast $u$ beyân ve şerh-i ayân olundığı üzre teşmîr-i şân-ı gayret ve ber-mûcib-i buyruldı âmil ve hareket ve muğâyir-i vaz' $u$ hareketden gâyet ittikâ ve mübâ'adet eyleyesüz deyü. Fì 13 Safer 1229. 


\section{TABLO I:}

Mehmed Ali Ağa'dan Üveys Bey'e Devir Edilen Gelir ve Masraflar

\begin{tabular}{|c|c|c|}
\hline Gelirler & Kuruş & Para \\
\hline Mart ayında İhtisâb hasılâtı & 598 & 29 \\
\hline Mart ayında Kapan hasılât & 1.891 & 25 \\
\hline Mart ayında Taşhân hasılâtı & 29 & 27 \\
\hline Mart ayında Meyd'n hasılâtı & 30 & 21 \\
\hline \multirow[t]{2}{*}{ Mart ayında Penbe narhiyesi hasılât } & 3 & 30 \\
\hline & 3.614 & 22 \\
\hline Mart ayında Mizân hâsılat & 77 & 10 \\
\hline Mart ayında Tahmîsden alınan peşinat & 1.000 & \\
\hline $\begin{array}{l}\text { Mart ayında yine Tahmîsden alınan } \\
\text { (Bedel-i iltizâmı } 2.750 \text { kuruş) }\end{array}$ & 250 & \\
\hline Mart ayında tabh ve Duhâniyyeden alınan & 1.616 & \\
\hline $\begin{array}{l}\text { Mart ayında bağ temessükâtundan ve öşr ve } \\
\text { kışlakçıdan ve sâ'ir aidatdan hasıl olunan }\end{array}$ & 1.384 & 20 \\
\hline \multicolumn{3}{|c|}{7.94212} \\
\hline Nisan ayında İhtisâb hasılâtı & 316 & 19 \\
\hline Nisan ayında Kapan hasılâtu & 3.628 & 4 \\
\hline Nisan ayında Taşhân hasılâtı & 119 & 16 \\
\hline Nisan ayında Meydân hasılâu & 21 & 27 \\
\hline \multirow[t]{2}{*}{ Nisan ayında Penbe narhiyesi hasılâtu } & 315 & 35 \\
\hline & 12.354 & 2 \\
\hline Nisan ayında Mizân hâsılatı & 27 & 2 \\
\hline
\end{tabular}

144 “Sene-i mezkûre Mart ibtidâsından mâh-ı Mays'in dördünci günine gelince atumşdõrt günde vâki' olan îrâd ve mesârifinin bâ-emr-i hazret-i veliyü'n-ni' amî ma' rifet ve ma' rifet-i şer'le rü'yet ve necâbetlü Üveys Bey'e teslîm ve redd olınan muhâsebelerinin defteridür". TŞS, 19 , 146. Bk. Tablo I. Ayrıca XVII. yüzyıl ortalarında Tokat Voyvodalığı'na bağlı kazalar, köyler, mahalleler ve kabileleri için bk. E. Özvar, aymı tez. Muhtelif tablolar. 


\begin{tabular}{|c|c|c|}
\hline Nisan ayında Tahmîsden alınan & 200 & \\
\hline Nisan ayında tabh ve Duhâniyyeden alınan & 896 & \\
\hline \multirow[t]{2}{*}{$\begin{array}{l}\text { Nisan ayında bağ temessükâtından hâsıl } \\
\text { olınan }\end{array}$} & 904 & \\
\hline & 14.428 & 6 \\
\hline Mayısın üç gününde İhtisâb hâsılatu & 415 & 25 \\
\hline Mayısın üç gününde Kapan hasılâtu & 311 & 30 \\
\hline Mayısın üç gününde Taşhan hasılâtu & 90 & 7 \\
\hline Mayısın üç gününde Meydan hasılâtu & 8 & 13 \\
\hline \multirow[t]{2}{*}{ Mizândan alınan Kudûmiyye } & 900 & \\
\hline & 16.154 & 1 \\
\hline Kazalardan alınan Kudûmiyye & 200 & 1 \\
\hline Kürkçülerden alınan Kudûmiyye & 200 & \\
\hline Basmacılardan alınan Kudûmiyye & 450 & \\
\hline Kazancılardan alınan Kudûmiyye & 500 & \\
\hline Kinisalardan alınan Kudûmiyye & 2.500 & \\
\hline \multirow[t]{2}{*}{ Tevzî' defterinde olan Tahsildâriye } & 5.000 & \\
\hline & 25.004 & \\
\hline \multicolumn{3}{|l|}{ Giderler } \\
\hline Mart ayında bâ-defter-i müfredât & 1.701 & \\
\hline Nisan ayında bâ-defter-i müfredât & 2.583 & \\
\hline İlbas olan hil'ât bahâ defter & 775 & \\
\hline İspenç kolcularına baftalık & 66 & \\
\hline \multirow[t]{2}{*}{$\begin{array}{l}\text { Bakır sarrafi vasıtasıyla İstanbul'a mersûl } \\
\text { poliçeyle taslim olınan }\end{array}$} & 12.000 & \\
\hline & 17.125 & \\
\hline Balâda muharrer îrâd-ı mukâta'a & 25.004 & \\
\hline Ber-vech-i bâlâ masraf fürû-nihâde & 17.125 & \\
\hline & 7.879 & $9=0$ \\
\hline
\end{tabular}

Kaynak: TȘS, 22, 94/1; Cevdet Maliye, No. 9279 
TABLO: II

Mukataa-i mezbûre malından tahsîl olunan mebaliğ beyân ${ }^{145}$

\begin{tabular}{|c|c|c|}
\hline & Kuruș & Para \\
\hline İhtisâb & 716 & 7 \\
\hline İhtisâb hevâ' 'isinden? & 420 & - \\
\hline İhtisâb kantârından & 1.100 & - \\
\hline Kapan-1 dakîk & 7.513 & 30 \\
\hline \multirow[t]{2}{*}{ Kapan teknesi avâ'idi } & 2.500 & - \\
\hline & 12.249 & 37 \\
\hline Taşhân & 270 & 37 \\
\hline Meydân & 163 & 24 \\
\hline Penbe nakliyesi & 1.204 & - \\
\hline Resm-i harîr & 191 & 20 \\
\hline \multirow[t]{2}{*}{ Resm-i mizân-ı harîr } & 603 & - \\
\hline & 14.682 & 39 \\
\hline Resm-i arûsan & 2.940 & - \\
\hline Resm-i tahsîl & 649 & 22 \\
\hline Resm-i ispenc ve duhâniye & 3.993 & 10 \\
\hline Cerâyim & 480 & - \\
\hline \multirow[t]{2}{*}{ İcâre bâgât } & 40 & - \\
\hline & 22.790 & 31 \\
\hline Nehc-i ferâğ-1 bâgât & 357 & - \\
\hline Bağ beylikçiliği avâ'idi & 250 & - \\
\hline Șem'-i hâne & 2.900 & - \\
\hline Tahmîs iltizâmından & 1.450 & - \\
\hline Sübaşılıkdan & 1.500 & - \\
\hline
\end{tabular}

145 “Zemân zabu Mart ibtidâsından olup şurûtu mûcibince Darbhâne-i Âmire tarafından zabt u idâre olınan mukāta 'âtdan Tokad Voyodalığı'nın binikiyüzotuziki senesine mahsûben ... sene-i mezkûre Teşrîn-i Sânî'sinin aluncı güninden Şubâtu gâyetine degin yüzotuzdört günde lâzım gelen îrâd-ı mukarrere-i mîrîyesinden ğayr-i ez-tahsîlât bakâyası ber-vech-i emâne bâ-emr-i âlî tahsilliyle me'mûr sa'âdetlü Dervị̂ Ali Ağa'nin ... müfredât defteridür". TŞS, 22, 94/1-95. 


\begin{tabular}{|c|c|c|}
\hline & 29.247 & 31 \\
\hline Etrâf-1 şehr a'şânından & 70 & \\
\hline Koyun-1 kışlak harcı & 238 & - \\
\hline Beytü'l-mal-1 Tokad & 1.901 & 37 \\
\hline Şarabhanelerden & 684 & 5 \\
\hline \multirow[t]{2}{*}{$\begin{array}{l}\text { Üveys Bey muhâsebesinden Çıldır valisine mekkâri } \\
\text { deyü mesârif kayd olunmıs iken tekrar edâmisin } \\
\text { den alınan }\end{array}$} & 1.500 & - \\
\hline & 33.641 & 33 \\
\hline \multirow[t]{2}{*}{$\begin{array}{l}\text { Üveys Beğin muhâsebesine dahil olmayan mizân } \\
\text { harîri edamisinden alınan }\end{array}$} & 967 & - \\
\hline & 67.090 & 3 \\
\hline \multicolumn{3}{|l|}{ Yalnız altmışyedibindoksan guruş 3 paradır. } \\
\hline \multicolumn{3}{|l|}{$\begin{array}{l}\text { Emsâli Âsitâne'de olan mukâta'ât-1 mîrî mebâliğ } \\
\text { beyân }\end{array}$} \\
\hline Gümüşhane & 933 & - \\
\hline Osman Sabit Efendi'den & 103 & - \\
\hline Sandık emîni Mustafa Efendi'de & 73 & - \\
\hline Def a mûmâ-ileyhde & 3 & $\underline{2}$ \\
\hline \multirow[t]{2}{*}{ İznikmid (İzmit) gümrük emîni } & 13 & \\
\hline & 1.126 & - \\
\hline Derfterdâr-1 sâbık Hacı Yusuf Efendi'de & 7 & $\underline{2}$ \\
\hline \multirow[t]{2}{*}{ Müteveffâ Abdullah Bey zimmetinde } & 301 & - \\
\hline & 1.434 & $\underline{2}$ \\
\hline \multicolumn{3}{|l|}{ Yalnız bindörtyüzotuzdört guruş yigirmi paradır. } \\
\hline \multicolumn{3}{|l|}{ El-mesârifât } \\
\hline Etbâ' ve tüfenkciyân civânlarına alınan şâ'ir & 1.005 & $\underline{2}$ \\
\hline $\begin{array}{l}\text { Der-i Aliyyeye hurûç medîne-i Tokad'a gelince ve } \\
\text { Şubat gâyetine degin eyyâm-1 mezkûrda olan ve } \\
\text { esnâ-yı râhîde mesârif-i matbah }\end{array}$ & 5.115 & \\
\hline İlbâs olınan hil'at behâ & 719 & - \\
\hline
\end{tabular}




\begin{tabular}{|c|c|c|}
\hline Konak kirâsı & 400 & - \\
\hline \multirow[t]{2}{*}{ Kapân ağası mâhiyyesi } & 350 & - \\
\hline & 7.590 & - \\
\hline Kethüdâ ve kâtib efendi mâhiyyesi mâh 5 & 2.000 & - \\
\hline Sâyis ve aşçlar ve saraydârlar mahiyyeleri & 384 & - \\
\hline \multirow[t]{2}{*}{$\begin{array}{l}\text { Amasya ve Bozok ve Divriği ve Niksar ve Köprü mîr- } \\
\text { illeri tahsildârlarma verilen }\end{array}$} & 1.003 & \\
\hline & 10.977 & \\
\hline $\begin{array}{l}\text { Yalnız onbindokuzyüzyetmişyedi guruş yigirmi pa- } \\
\text { radır. }\end{array}$ & & - \\
\hline \multicolumn{3}{|c|}{ Mukataa-i mezkûre malından olub mütemennü'l-husûl olan beyan } \\
\hline Memlaha-i Sarı Kıșla & 717 & \\
\hline Hulvar & 22 & 20 \\
\hline Güngörmez & 14 & 20 \\
\hline Mezre'a-i Derbülendlü ve Rücûk? & 41 & - \\
\hline \multirow[t]{2}{*}{ Irak Acemi } & 103 & - \\
\hline & 398 & $40 ?$ \\
\hline Ahmed Alanı & 38 & - \\
\hline Kızılöz & 35 & 20 \\
\hline Mezre'a-i Hokmar ve Sulu hali & 20 & - \\
\hline Furû-nihâ-i ehl-i Diyorki? & 170 & 20 \\
\hline \multirow[t]{2}{*}{ Yaylaklu ve Oluk } & 6 & - \\
\hline & 667 & 20 \\
\hline Ekrâd-ı Saraycık & 135 & - \\
\hline Kabîle-i Olukmânı & 164 & 20 \\
\hline Akkuzulı & 197 & - \\
\hline Beytü'l-mâl-1 Samsun & 21 & - \\
\hline \multirow[t]{2}{*}{ Memlaha-i Huradır arâzi-i Hunuk-1 kışla } & 10 & \\
\hline & 1.190 & - \\
\hline Şarkîpâre kabîlesinden & 540 & 20 \\
\hline Sıraç kabîlesinden & 1.976 & 30 \\
\hline
\end{tabular}




\begin{tabular}{|c|c|c|}
\hline & 3.712 & 10 \\
\hline \multicolumn{3}{|c|}{ Yalnız üçbinyediyüzoniki guruş on pâredir. } \\
\hline \multicolumn{3}{|c|}{ Mukāta'a-i merkūm malından olup bakâyâ kalan meblağ esâmîsi beyân } \\
\hline Niyâbet & 39,5 & - \\
\hline Taksit-i râbi' Amasya & 577 & - \\
\hline Behram Pașa'dan & 106 & - \\
\hline Mezra'a-i Dereçiği & 94 & - \\
\hline \multirow[t]{2}{*}{ Ilbeylü'de } & 9.200 & - \\
\hline & 10.016 & 0,5 \\
\hline Şarkîpâre & 219 & 0,5 \\
\hline Oyuk & 73 & 0,5 \\
\hline Citak Hacı & 22 & - \\
\hline Çıtak Hacı diğer hisse & 22 & - \\
\hline \multirow[t]{2}{*}{ Sakallu Seyh } & 28 & - \\
\hline & 10.381 & 0,5 \\
\hline Elmahacilu & 56 & - \\
\hline İncesu İlaldı & 29 & - \\
\hline Dere Kilisa & 7 & 0,5 \\
\hline İlyasa Fakiyelü & 4 & 0,5 \\
\hline \multirow[t]{2}{*}{ Kara Hacılu } & 49 & - \\
\hline & 10.527 & 0,5 \\
\hline Kabîle-i Çepni & 1.114 & - \\
\hline İrâkil & 97 & 0,5 \\
\hline İsa Kebir & 18 & 0,5 \\
\hline Sarta & 197 & - \\
\hline Deveciler & 142 & - \\
\hline \multirow[t]{2}{*}{ Ömer Bey Saray } & 50 & 30 \\
\hline & 12.147 & 30 \\
\hline Yalnız onikibinyüzkırky & & \\
\hline
\end{tabular}

Kaynak: TŞS, 19, 146; Cevdet Maliye, No. 9279. 
TABLO III.

TOKAT VOYVODALARI VE TOKAT VOYVODALIĞI VE TEVÂBI'‘ MUKATAASI'NIN IILTIZAM BEDELLERI

\begin{tabular}{|c|c|c|c|}
\hline $\begin{array}{l}\text { Tarih } \\
\text { Hicri }\end{array}$ & İltizam sahipleri ve voyvodalar & $\begin{array}{l}\text { İltizam bedelleri } \\
\text { (Ylllk - Kuruş) }\end{array}$ & Kaynak \\
\hline 1070 & Galata voyvodası Küçük Ahmed Ağa & $\begin{array}{l}67.491 \text { kuruştan } \\
24.230 \text { 'u ber-vech-i } \\
\text { voyvodalı } 43.257 \\
\text { kuruşu iltizamla sa- } \\
\text { tılmıșur. }\end{array}$ & $\begin{array}{l}\text { E. Özvar, aynı } \\
\text { tez, s. } 38 .\end{array}$ \\
\hline 1083 & Gürcü Osman Ağa & 63.541 & $\begin{array}{l}\text { Cevdet Maliye, } \\
22201 .\end{array}$ \\
\hline 1085 & Gürcü Osman Ağa & 6.356 .100 akçe & $\begin{array}{l}\text { E. Özvar, aynı } \\
\text { makale, } \\
\text { s. } 1633 \text {. }\end{array}$ \\
\hline 1185 & Abdullah Ağa & - & TSS $01,33 / 2$. \\
\hline 1187 & $\begin{array}{l}\text { Canik muhassılı ve Amasya mutasar- } \\
\text { rifi Hacı Ali Pașa }\end{array}$ & - & TŞS $01,212 / 2$. \\
\hline 1197 & Kadir Efendizâde & - & $\begin{array}{l}\text { Cevdet Maliye, } \\
26605 \text { L. }\end{array}$ \\
\hline 1200 & Ekmekçi İbrahim & - & TŞS $02,122 / 1$. \\
\hline $\begin{array}{l}1201- \\
1202\end{array}$ & Lütfullah Bey & - & TŞS $03,48 / 2$. \\
\hline $\begin{array}{l}1205- \\
1206\end{array}$ & Yağcioğlu Mehmed Bey & - & TŞS $02,121$. \\
\hline $\begin{array}{l}1208- \\
1211\end{array}$ & Lütfullah Bey & 56.500 & $\begin{array}{l}\text { TŞS } 02,58 / 2 . \\
\text { TŞS } 03,48 / 3 \text {. }\end{array}$ \\
\hline $\begin{array}{l}1210- \\
1211\end{array}$ & Lütfullah Bey & - & $\begin{array}{l}\text { TŞS } 03,48 / 2 \text {; } \\
\text { TŞS } 02,147 / 2 \text {. }\end{array}$ \\
\hline $\begin{array}{l}1212- \\
1213\end{array}$ & $\begin{array}{l}\text { Yağcıoğlu Mehmed Bey; } \\
\text { Voyvoda vekili Üveys Bey; } \\
\text { Lütfullah Bey }\end{array}$ & - & $\begin{array}{l}\text { TŞS } 03,36 \text {; } \\
\text { TŞS } 04,107 / 1 \text {; } \\
\text { TŞS } 05,52 / 1 \text {. }\end{array}$ \\
\hline $\begin{array}{l}1213- \\
1214\end{array}$ & $\begin{array}{l}\text { Lütfullah Bey; } \\
\text { Osman Ağa }\end{array}$ & - & $\begin{array}{l}\text { TŞS } 06,65 \\
\text { TŞS } 7,77 / 2 .\end{array}$ \\
\hline 1215 & $\begin{array}{l}\text { Osman Ağa; } \\
\text { Ömer Ağa; } \\
\text { Üveys Bey }\end{array}$ & - & $\begin{array}{l}\text { TŞS } 7,77 / 2 \text {; } \\
\text { H. Cinlioğlu, } \\
\text { aynı eser, C. } \\
\text { III, s. } 188 .\end{array}$ \\
\hline
\end{tabular}




\begin{tabular}{|c|c|c|c|}
\hline $\begin{array}{l}1215- \\
1217\end{array}$ & Üveys Bey & - & $\begin{array}{l}\text { TŞS } 07,52 / 2 \text {; } \\
\text { H. Cinlioğlu, } \\
\text { aynı eser, C. } \\
\text { III, s. } 188 .\end{array}$ \\
\hline $\begin{array}{l}1218- \\
1220\end{array}$ & İlbaşıoğlu Küçük Ahmed Ağa & - & $\begin{array}{l}\text { TŞS } 09,179 / 5 \\
\text { TŞS } 09,79 / 1\end{array}$ \\
\hline 1220 & $\begin{array}{l}\text { Kuruoğlu Hasan Ağa (Mahmud Tay- } \\
\text { yar Paşa tarafindan) }\end{array}$ & - & $\begin{array}{l}\text { TŞS } 09,81 / 1 \text {; } \\
\text { H. T. Cinli- } \\
\text { oğlu, aynı } \\
\text { eser, III, s. } 44- \\
45 .\end{array}$ \\
\hline $\begin{array}{l}1220- \\
1222\end{array}$ & İlbașıoğlu Küçük Ahmed Ağa & - & $\begin{array}{l}\text { TŞS } 10,99 / 1 \\
\text { TŞS } 11,90 / 2\end{array}$ \\
\hline $\begin{array}{l}1222 / \\
1807\end{array}$ & $\begin{array}{l}\text { İlbaşıŏlu Küçük Ahmed Ağa; } \\
\text { Mehmed Metin }\end{array}$ & - & TŞS $11,90 / 2$. \\
\hline 1223 & $\begin{array}{l}\text { Mehmed Metin; } \\
\text { Mustafa; }\end{array}$ & - & TŞS $12,9 / 1$. \\
\hline 1224 & $\begin{array}{l}\text { Hassa silahşörlerinden Mehmed } \\
\text { Behlül Bey }\end{array}$ & $\begin{array}{l}\text { Nisf hissesiyle nısf-1 } \\
\text { südüs an sümün } \\
\text { hissesi } 59.283\end{array}$ & $\begin{array}{l}\text { TŞS } 12,46 / 2 \text {; } \\
\text { TŞS } 12,47 / 1 \text {. }\end{array}$ \\
\hline 1225 & Hassa silahşörlerinden Ali Ağa & $\begin{array}{l}\text { Nısf hissesiyle nısf-1 } \\
\text { südüs an sümün } \\
\text { hissesi } 59.283\end{array}$ & TŞS $13,67 / 2$. \\
\hline 1226 & Hassa silahşörlerinden Ali Ağa & $\begin{array}{l}\text { Nısf hissesiyle nısf-1 } \\
\text { südüs an sümün } \\
\text { hissesi } 59.283\end{array}$ & TŞS $14,138 / 3$. \\
\hline 1227 & Mehmed Salih Ağa & $\begin{array}{l}\text { Nısf hissesiyle nısf-1 } \\
\text { südüs an sümün } \\
\text { hissesi } 60.000\end{array}$ & TŞS $15,75 / 2$. \\
\hline 1228 & $\begin{array}{l}\text { Mehmed Salih Ağa; } \\
\text { Erzurumlu Hacı Yusufzâde Yusuf } \\
\text { Ağa }\end{array}$ & $\begin{array}{l}\text { Nisf hissesiyle rub'-1 } \\
\text { südüs hissesi } 64.000 \\
\text { Beyhan Sultan'ın } \\
\text { rub' hissesiyle diğer } \\
\text { hisseler }\end{array}$ & $\begin{array}{l}\text { TŞS } 16,37 / 2 \\
\text { TŞS } 17,29 / 1\end{array}$ \\
\hline
\end{tabular}




\begin{tabular}{|c|c|c|c|}
\hline 1229 & $\begin{array}{l}\text { Ber-vech-i emânet Sivas valisi İbra- } \\
\text { him Paşa Silahdârı Gürcüzâde } \\
\text { Mehmet Ağa }\end{array}$ & - & TŞS $18,70 / 1$. \\
\hline 1230 & $\begin{array}{l}\text { Emaneten Sivas valisi Galip Paşa ha- } \\
\text { zinedân Mehmed Ali Ağa ( } 64 \text { gün); } \\
\text { Seyyid Hacı Üveys Bey }\end{array}$ & $\begin{array}{l}\text { Nısf hissesiyle rub'-1 } \\
\text { südüs hissesi } \\
64.000\end{array}$ & $\begin{array}{l}\text { TŞS } 19,105 / 1 \text {; } \\
\text { TŞS } 19,139 ; \\
\text { TŞS } 19,146 ; \\
\text { TŞS } 20,174 / 2 \text {. }\end{array}$ \\
\hline 1231 & $\begin{array}{l}\text { Emâneten Abdüllatifzâde Hüseyin } \\
\text { Ağa; } \\
\text { Katuroğlu Üveys Bey }\end{array}$ & - & TŞS 20, 49 . \\
\hline 1232 & $\begin{array}{l}\text { Katuroğlu Üveys Bey; } \\
\text { Emâneten Selanik tütün gümrüğü } \\
\text { eski emini Derviş Ali }\end{array}$ & - & $\begin{array}{l}\text { TŞS } 21,67 \\
\text { TŞS } 22,52 \\
\text { TŞS } 22,55 / 1 \text {. }\end{array}$ \\
\hline 1233 & $\begin{array}{l}\text { Selanik tütün gümrüğü eski emini } \\
\text { Derviş Ali }\end{array}$ & $\begin{array}{l}\text { Nisf hissesiyle rub'-1 } \\
\text { südüs hissesi } 64.000\end{array}$ & $\begin{array}{l}\text { TŞS 22, 89/1; } \\
\text { TŞS 22, 89, } 2 .\end{array}$ \\
\hline 1234 & $\begin{array}{l}\text { Selanik tütün gümrüğü eski emini } \\
\text { Derviş Ali }\end{array}$ & $\begin{array}{l}\text { Nısf hissesi Darb- } \\
\text { hâne-i Âmire } \\
\text { Diğer nısf hissesi } \\
\text { müşterekleri uhde- } \\
\text { lerinde } 19.000 \\
\text { Nısf hissesiyle rub'-1 } \\
\text { südüs hissesi } \\
\quad 64.271\end{array}$ & TŞS $24,4 / 2$. \\
\hline 1235 & Süleyman Rifat Ağa & 64.271 & TŞS $26,44 / 1$. \\
\hline 1236 & Hassa silahşörlerinden Hacı Ali Ağa & 64.271 & TŞS 27, 139. \\
\hline 1237 & $\begin{array}{l}\text { Hassa silahşörlerinden Hacı Ali Ağa; } \\
\text { Salih Ağa }\end{array}$ & $\begin{array}{l}\text { Nisf hissesiyle rub'-1 } \\
\text { südüs hissesi } 64.271\end{array}$ & $\begin{array}{l}\text { TŞS 27,139/1; } \\
\text { TŞS 27,139/2; } \\
\text { TŞS 28, 20/1; } \\
\text { TŞS 28, 20/2. }\end{array}$ \\
\hline 1238 & Salih Ağa & - & \\
\hline 1239 & Salih Ağa & $\begin{array}{l}\text { Nısf hissesiyle rub'-1 } \\
\text { südüs ve rub'-1 sü- } \\
\text { mün hissesi } \\
67.980\end{array}$ & TŞS $28,164 / 2$. \\
\hline
\end{tabular}




\begin{tabular}{|c|c|c|c|}
\hline 1240 & $\begin{array}{l}\text { Hassa silahşörlerinden Süleyman } \\
\text { Ağa }\end{array}$ & $\begin{array}{l}\text { Nisf hissesiyle rub'-1 } \\
\text { südüs ve rub'-1 sü- } \\
\text { mün hissesi } \\
67.980 \\
\text { rub' hissesi } \\
\quad 54.100 \\
\end{array}$ & $\begin{array}{l}\text { TŞS 29, 95/2; } \\
\text { TŞS } 29,96 / 1 \text {. }\end{array}$ \\
\hline 1241 & $\begin{array}{l}\text { Hassa silahşörlerinden Süleyman } \\
\text { Ağa }\end{array}$ & $\begin{array}{l}\text { Nısf hisse ile üç } \\
\text { sümün an rub } \\
\left.\text { (çeyreğin } 3 / 8^{\prime} i\right) \\
\text { hisse } \\
\quad 70.470,5\end{array}$ & $\begin{array}{c}\text { TŞS } 30,8 / 2-3 ; \\
\text { TŞS } 31,69 .\end{array}$ \\
\hline 1242 & $\begin{array}{l}\text { Sivas valisi silahdarı İsmail Ağa; } \\
\text { Abdüllatifzâde Hüseyin Ağa }\end{array}$ & - & $\begin{array}{l}\text { TŞS } 31,69 ; \\
\text { TŞS } 31,114 \\
-115 ; \\
\text { TŞS } 32,110 / 1 .\end{array}$ \\
\hline 1243 & Abdüllatifzâde Hüseyin Ağa & - & TŞS $32,110 / 1$. \\
\hline 1244 & $\begin{array}{l}\text { Abdüllatifzâde Hüseyin Ağa; } \\
\text { Mehmed Hanefi Ağa }\end{array}$ & - & $\begin{array}{l}\text { TŞS } 34,33 / 2 \text {; } \\
\text { TŞS } 34,82 / 1\end{array}$ \\
\hline 1245 & $\begin{array}{l}\text { Halil Ağa; } \\
\text { Dergâh-1 'âlî gediklilerinden Meh- } \\
\text { med Ağa }\end{array}$ & $\begin{array}{l}5 \text { sümün }(5 / 8) \\
\text { hisse muktâta'ât } \\
\text { hazinesi tarafından } \\
\text { zabt ve idare } 74.362\end{array}$ & $\begin{array}{l}\text { TŞS } 35,10 \text {; } \\
\text { TŞS } 35,88 / 1\end{array}$ \\
\hline 1246 & Abdüllatifzâde Hüseyin Ağa & Rub` hissesi 54.100 & $\begin{array}{l}\text { TŞS } 36,47 / 2 \text {; } \\
\text { H. Cinlioğlu, } \\
\text { aynı eser, III, } \\
\text { s. } 190 .\end{array}$ \\
\hline 1247 & Ömer Efendi & $\begin{array}{l}\text { Beş sümün }(5 / 8) \\
\text { hisse } 90.362\end{array}$ & $\begin{array}{l}\text { TŞS } 37,35 / 1 \\
\text { TŞS } 37,97 / 2 \text {. }\end{array}$ \\
\hline 1248 & $\begin{array}{l}\text { Ömer Ağa; } \\
\text { Abdullah Ağa }\end{array}$ & - & $\begin{array}{l}\text { TŞS } 38,54 / 2 \\
\text { TŞS } 38,104 / 4 .\end{array}$ \\
\hline 1249 & Abdüllatifzâde Hüseyin Ağa & - & $\begin{array}{l}\text { TŞS } 38,142 / 2 \text {; } \\
\text { TŞS } 39,88 / 1\end{array}$ \\
\hline $\begin{array}{l}1250- \\
1251\end{array}$ & $\begin{array}{l}\text { Dergâh-1 âli kapıcıbaşılarından Hü- } \\
\text { seyin Bey }\end{array}$ & - & $\begin{array}{l}\text { TŞS } 40,155 / 2 \text {; } \\
\text { TŞS } 40,83 / 2 \text {; } \\
\text { TŞS } 47 .\end{array}$ \\
\hline
\end{tabular}




\begin{tabular}{|c|c|c|c|}
\hline 1252 & $\begin{array}{l}\text { Dergâh-1 âli kapıcıbaşılarından Hü- } \\
\text { seyin Bey; } \\
\text { Vekaleten Latifzâde Hüseyin Ağa; } \\
\text { Sivas kaymakamı Mir Ali buyruldu- } \\
\text { suyla Hacı İzzet Ağa }\end{array}$ & - & $\begin{array}{l}\text { TŞS } 49,29 / 2 \text {; } \\
\text { TŞS } 45 / 2 \text {. }\end{array}$ \\
\hline 1253 & $\begin{array}{l}\text { Sivas kaymakamı Mir Ali buyruldu- } \\
\text { suyla Hacı İzzet Ağa }\end{array}$ & - & TŞS 49,186/1. \\
\hline 1254 & $\begin{array}{l}\text { Latifzâde Hüseyin Ağa } \\
\text { Amasya Sancağı mütesellimi ve To- } \\
\text { kad voyvodası Ahmed }\end{array}$ & - & TŞS 51, 138. \\
\hline 1255 & $\begin{array}{l}\text { Amasya Sancağı mütesellimi ve To- } \\
\text { kad voyvodası Ahmed }\end{array}$ & - & $\begin{array}{l}\text { TŞS } 52,6 . \\
\text { TŞS } 52,66 / 1 .\end{array}$ \\
\hline 1256 & $\begin{array}{l}\text { Maliye işleri/Tokat Muhassılı Hasan } \\
\text { Ağa } \\
\text { Zabtiye işleri/ Miralay Mustafa Beye- } \\
\text { fendi }\end{array}$ & - & $\begin{array}{l}\text { TŞS } 54,46 / 1 \\
\text { TŞS } 54,92 / 1\end{array}$ \\
\hline 1257 & $\begin{array}{l}\text { Muhassıl vekili Mehmed Ağa } \\
\text { Muhassıl Hilmi } \\
\text { Zabtiye memuru Hacı Hasan }\end{array}$ & - & $\begin{array}{l}\text { TŞS } 54,136 / 2 \text {; } \\
\text { TŞS } 54,5 \text {. }\end{array}$ \\
\hline
\end{tabular}

Not:

1. 1214-1222 arasında Tokat voyvodalığı ve tevâbi‘ mukāta'asının asıl sahibi Cabbarzâde Süleyman Bey'dir. Bu dönemde voyvodaları kendi atamıştur.

2. 1228-1232 arasından Tokat voyvodalığı ve tevâbi mukataasının asıl sahipleri Sivas valileriydi. Voyvodalar da bunlar vasıtasıyla atanmışur.

3. 1245-1247 arası voyvodalar, Tokat voyvodalığı ve tevâbi mukataasının asıl sahibi Dergâh-1 âlî kapıcıbaşılarından Amasya Sancağı mütesellimi Hafız Hasan Ağa tarafindan atanmıştur.

4. 1248 yılında Abdullah Ağa ve 1249 'da Abdüllatifzâde Hüseyin Ağa, iltizamın asıl sahibi Amasya sancağı mütesellimi ser-bevvâbin-i dergâh-1 âlî Mîr Ahmed tarafından atanmış, aynı yıl voyvodalık Sivas valisi Hazinedarzâde Osman Paşa'ya verildiğinden Hüseyin Ağa vekaleten yürütmüştür.

5. 1250'de voyvoda Sivas valisi Reşid Mehmed Paşa tarafından atanmışur.

6. 1252'de Hüseyin Bey'in azliyle, Sivas kaymakamı Mîr Ali tarafından Latifzâde Hüseyin Ağa voyvodalığa vekaleten atanmıştır.

7. 1229 tarihli bir belgede Tokat Voyvodalığı ve tevâbi ' malı olarak 76.531 Kuruş 38 akçe ifadesi geçmektedir. TŞS, 17, 143 
